School of Economics and Commercial Law, Goteborg University Department of Law

\title{
Islam and Human Rights
}

Masters Thesis

(Uppsats Tillämpade studier 20p)

Student: Malin Delling

Supervisor: Per Cramér, Professor of International Law and Jean Monnet Chair in European Integration Law

VT 2004 


\section{Table of contents}

\section{Introduction 4}

II Method and disposition 5

\section{Universal Human Rights 6}

1.1 The idea of universal human rights 6

1.2 Human Rights in theory 7

1.3 Human Rights in practice 8

2. Cultural relativism 11

2.1 Universality versus relativism 11

2.2 Cultural Diversity in a Western perspective 12

2.3 Islam and Cultural diversity 13

\section{Islam and Sharia 17}

3.1 The history of Islam 17

3.1.1 The Prophet 17

3.1.2 The "Rightly Guided" caliphs 19

3.2 Islamic law 21

3.2.1 Primary sources 21

3.2.1.1 The Qur'an 21

3.2.1.2 The Sunna 21

3.2.2 Secondary Sources of Law 23

4. Regional Human Rights development in theory 25

4.1 The Theocentric versus the Anthropocentric difference 25

4.2 Problem areas in Islamic Human Rights Documents 27

4.2.1 Unequality between the sexes 27

4.2.2 Rights of non-Muslim minorities 30

4.2.3 Freedom of religion 31

4.3 Islamic documents on Human Rights 31

4.3.1 Human Rights in Islam - A. A. Mawdudi 197533

4.3.1.1 General human right 33

4.3.1.2 The rights of citizens in an Islamic state 38

4.3.2 The Universal Islamic Declaration of Human Rights (UIDHR) 41

4.3.3 The Cairo Declaration on Human Rights in Islam 199046

4.3.4 Arab Charter of Human Rights 199450 
5. Regional Human Rights development in practice 54

5.1 Limitation 54

5.2 Development on the governmental level 55

5.2.1 Commitment to the International documents on Human Right 55

5.2.2 Governmental "human rights departments" 56

5.2.3 “Governmental" human rights NGOs 57

5.3 The local Human Rights movements in the Arab countries 57

5.3.1 Independent Human Rights NGOs 58

5.3.2 The problems of Arab human rights NGOs 61

5.4 Islamic Fundamentalism and Human Rights 64

6. Conclusion 68

Literature 75

Appendix:

The Cairo Declaration of Human Rights

The Arab Charter on Human Rights 


\section{Introduction}

Sometime shortly after September $11^{\text {th }} 2001$, when the World Trade Center was a pile of ashes, and the world suddenly had turned into a place where it came much more clear how large the gap between East and West, and between the rich North and the poorer South had become, I started wondering about prejudice and incompatibility of cultures. Most of all I felt, in a climate where Islam suddenly was pointed out as a source of barbarism and terrorism, how little I actually knew about this the third largest religion of the world and its influences on civil and political life in the countries considered Islamic. One often hears about the Islamic Law - the Sharía, and how it's inhuman punishments and discriminatory rules, for example for women, are totally incompatible with our Western standards of human rights and "civilized" morals. But is Islamic law as such contradictory to International Human Rights, or are the violations of personal rights in the name of Islam rather a consequence of cruel regimes and historically established traditions? Is there a human rights discourse in the Islamic world, or is the general opinion that these westerly-based philosophies are something forced upon them in a neo-colonial way? My objective with this essay is to gain a deeper understanding of the fundaments of Islamic Law. I will try to establish whether a legal system based on it would be compatible with the universal human rights, as defined by the UN, or not. I also want to find out whether the governments of the Islamic countries have an official standpoint concerning human rights and international law. Achieving this turned out to be much more complicated than I had imagined. The Islam I came across in my research was very different and far more diverse than the generalized media-picture, often focused on furious masses of men with beard screaming "Allah akbar" and "Death to the US", or obedient women completely covered in black burqas. Within Islam there exists numerous ways of interpretation. The difference between for example fundamentalism and reformism is in parts so large it is like dealing with two separate religions. There are also evidently very different levels of secularization among the Islamic countries. Saudi Arabia, one of the most conservative Islamic countries, has a legal system almost entirely based on Sharía, while the countries in North Africa, for example Tunisia and Egypt are a rather secularized. The comparisons made between international law and Islamic law will consequently be made at a much-generalized level. It also constituted a problem that most of the material available on the subject of Islamic law and human rights are written by western scholars and from a westernized perspective. I've tried to be as objective as possible, and consider the Islamic 
angle too, but the difficulty in finding accurate material and of course the disadvantage of from the beginning having a "western" point of view complicated it further.

\section{Method and disposition}

Since my purpose has been to find out the position of human rights in the Islamic world, I chose to do so from two different angles, one theoretic and one practical. My emphasis will be on the theoretic one, in analyzing documents on human rights produced in an Islamic environment. In doing this I will try to establish a generalized standpoint on human rights in the light of an Islamic worldview, and analyze its compatibility with our western human rights. The definition of human rights I will apply, as foundation of comparison, will be that established by the UN in the International Bill of Human Rights ${ }^{1}$. One can of course argue about whether the UN documents are the only accurate way of defining which rights are universal and relevant to protect. But since most states have signed at least the UDHR and the two Covenants, and considering the fact that there really isn't any other alternative definition agreed upon by a larger community, this will be my ground of comparison. Before the analyze of the Islamic human rights documents, I will however begin with a brief introduction to the history of human rights according to the definition I chosen. I will furthermore introduce the concept of cultural relativism. My purpose with this is not to actually discuss whether what we call universal human rights correctly can be applied everywhere in the world, or actually lay claim on being universal. Cultural relativism, as I will show, on the contrary claims that the UN standards rather are a western idea and that we must consider adapting a more culturally sensitive approach to human rights. Moral standards differ in various cultures and it is presumptuous of us to assume that ours necessarily are the right ones. My reason for briefly including the discussion on cultural relativism is the interest shown for this matter in the human rights discourse in later years, especially in the Middle East. Most of the documents included in the later analyze are produced with the purpose of being culturally adjusted alternatives to the UN documents. I will however refrain from taking a stand on the subject of whether human rights can be justified as universal. My purpose of this essay is not to prove cultural relativism right or wrong, I will simply uncritically presume the international standard of human rights as the standard I compare Islamic law against.

Last, as the practical aspect of the subject of human rights in the Islamic world, I will try to establish to what extent active human rights work exists in Islamic (or rather Arabic) 
countries, both on a governmental and non-governmental level. My main focus will be the existence of local and regional human rights NGOs and the obstacles they meet in their activity. I will also briefly discuss whether there is any human rights activity within the fundamentalist movements.

In choosing my sources I have tried to get a balance between western and Islamic scholars. It constituted a problem to find material from the Islamic view that was translated to English. Most of the material written by Muslims that I have used is by Muslims active at universities in the USA or Europe. Among these a liberal, reformist view on Islam is dominating, since not many (if any..) conservative Muslims are tied to western universities. In trying to describe a more conservative side of the Islamic human rights discourse, I've consequently had to rely mostly on western literature rendering the opinions of the conservatives. The Islamic human rights documents I'm using in my analysis are either documents that are produced at a governmental level, as for example the Cairo Declaration on Human Right or the Arab Charter of Human Rights. The other category are documents, such as the human rights document by Mawdudi, can be seen as authoritative doctrine since experts on Islamic law from western universities, such as Mayer, Dalacoura and An-Naim, often refer to them.

\section{Universal Human Rights}

\subsection{The idea of universal human rights}

Human rights can be described as rights one has simply because one is human ${ }^{2}$. They are the rights to especially basic freedom and security, without which a person's existence would be considered less than human ${ }^{3}$. Human rights are universal, and as such they have predominance over other rights given to people for other different reasons. Human rights are hold equally by all humans because "being human cannot be renounced, lost, or forfeited, human rights are inalienable" ${ }^{\prime 4}$. This, of course, does not apply in reality. Not all people enjoy the same human rights in practice, but the basic idea is that they still have the same human rights and hold them equally and inalienably. Rights can generally be seen as the relationship between the right-holder and the duty-bearer. This relationship is largely under the control of

\footnotetext{
${ }^{1}$ The Universal Declaration of Human Rights, the International Convenant on Civil and Political Rights and the International Convenant on Economic, Social and Cultural Rights.

${ }^{2}$ Donally Jack, International Human Rights, Westview Press 1998, Second edition p18

${ }^{3}$ Dalacoura Katerina ,Islam, liberalism and human rights, I.B Tauris Publishers, New York ,1998, p 6

${ }^{4}$ Donally p 18
} 
the right-holder, since his right is inalienable, independent of obligation and can be exercised after his will.

\subsection{Human Rights in theory}

The principle of individual Human Rights can be traced to primarily two strands of Western philosophical and political thought; natural law and the Enlightenment. ${ }^{5}$ The idea of natural law - a higher law that stands over the laws made by man and is binding on our conscience, can be found as early as in Sophocles's Antigone. The idea was fully established by the Stoic philosophers in the Hellenistic period. ${ }^{6}$ They introduced the concept that there were rights and obligations, which belonged to the individual because of his virtue as being human rather than being a member of the city-state. Similar thoughts are found in the medieval Christianity, in particular by Thomas ab Aquino. His definition of natural law, however, emphasized the individual's participation in divine law and was a guide to morality and ethics. ${ }^{7}$ The rights of the individual, as we understand them today, emerged with the Enlightenment. The earlier ideas of natural law didn't have a political content. They didn't determine the relationship between the individual and the state i.e. the right-bearer and the duty- holder. The Enlightenment put the individual in centre and " divorced knowledge from revelation"s. During this period in Western history, beginning in the $17^{\text {th }}$ century, we can see the start of what is going to develop into the secularized society that now is what separates us from most other parts of the world, where religion still plays a greater part in people's lives. The idea of a natural law without a base in religion started with the English philosopher John Locke, probably the most important natural law theorist in modern times. Locke argued in detail that some rights self-evidently pertain to individuals as human beings. The most important rights were the rights to life, liberty and property, but the individual has given up the right to enforce this through a "social contract" to the state (however not given up the right itself..) ${ }^{9}$. The ideas of individualism and the rights of humans could also be found later in the works of other philosophers of the Enlightenment, such as Rousseau, Montesquieu and Voltaire. It was also these liberal ideas that were to become the ideological foundation both of the English, American and French revolutions, and the different declarations and new constitutions that

\footnotetext{
${ }^{5}$ Dalacoura, p 6

${ }^{6}$ Ibid

${ }^{7}$ Ibid

${ }^{8}$ Ibid $\mathrm{p} 7$

${ }^{9}$ Steiner \& Alston, International Human Rights in Context, Oxford University Press 2000, Second Ed, p 324
} 
followed them. The ideas of natural rights overthrew ideas such as the divine rights of kings, since no political regime was justified unless it satisfied the natural rights of its citizens. The connection between these new ideas and the revolutions of the people was obvious. The debate over human rights as a universal concept rooted in natural law and rationalism did however have many critics, also in the Western sphere. In England, for example, conservatives such as Burke and Hume condemned the doctrine partly in fear of that a public affirmation of natural rights would lead to social upheaval, or natural rights becoming a substitute for effective legislation ${ }^{10}$. Bentham, one of the founders of Utilitarianism, claimed that natural law could only be the root of "imaginary rights", as it itself is an imaginary law. Real rights, he said, could only come from real laws. The utilitarian idea of the greatest happiness principle can lead to sacrificing the rights of some individuals to gain happiness for a larger group of others. ${ }^{11}$ According to this theory human rights do not have an independent moral statues or force. Even John Stuart Mill, on of the greatest defenders of liberalism, claimed that rights are ultimately founded on utility ${ }^{12}$.

One problem in the justification of human rights based in the ideas of the Enlightenment is the separation of nature law from God and revelation. Without being able to justify the rights of man as given by God and therefore absolute, the moral foundation of the theory gets more vulnerable and is an easy target for criticism. This disadvantage, as we will see later, is especially relevant in the discourse with those critics of human rights who claim them to have no validity in a multi-cultural world, or that a system of rights given by God, such as the Sharía - the Islamic law, can’t possibly be inferior to a man-made set of moral rules.

\subsection{Human Rights in practice}

Even though the concept of human rights is no novelty in our western sphere of ideas, it was not until after the systematic murders of innocent during the Second World War that human rights became an issue in international politics. Before that most states systematically violated these rights, for example the racial discrimination in the US or the violations the colonial empires brought about for the indigenous people of the colonies. Human rights were however considered a domestic political matter and intervention from other states was not an option. In international relations during the past three centuries the principle of sovereignty has been

\footnotetext{
${ }^{10}$ Steiner \& Alston p 325-326

${ }^{11}$ Ibid p 326

12 Ibid p 326
} 
dominating. The principle has its origin in the creation of nation-states, basically during the Enlightenment. The duty correlative to sovereignty is non-intervention, and there was consequently no possibility for one state to have opinions on another state's violation of human rights. The discussions of humanitarian law in the beginning of the $20^{\text {th }}$ century, such as the Laws of War expressed in the 1907 Hague Conventions, were limited to the rights of foreign nationals and did not limit what a state could do to its own citizens, or people in its colonies. There has however been a change in this during the past fifty years. The catalyst for human rights as a topic of international action, was as mentioned above, the Holocaust - the genocidal massacre of millions of innocent, mainly Jews, but also Gypsies, Communists, Social Democrats, homosexuals and other dissidents ${ }^{13}$. During the war there was very little effort made, even among the Allied, to do something to stop the massacre. This lead to a common feeling of guilt after the war, which in its turn led to an increased concern for human rights. The first step was the Nuremberg War Crimes Trials (1945-46), where leading Nazis where prosecuted for their crimes against humanity. In 1948, on December 9, the Convention on the prevention and Punishment of the Crime of Genocide was open for signature. The day after that, December 10 the UN General Assembly adopted the Universal Declaration of Human Rights, which still today is the most authoritative statement of international human rights norms. The Universal Declaration of Human Rights was a resolution and not a treaty; it is therefore not per se legally binding. Its drafters intended to let the resolution be followed by a covenant (treaty), but due to ideological rivalry, mainly over the status of economic and social rights, the covenant was tabled for more than a decade. In 1966 the codification was finally completed. It was called the International Rights Covenants and had been, as a consequence of the earlier indifferences, broken in two; the International Covenant on Civil and Political Rights and the International Covenant on Economic, Social and Cultural Rights. These two Covenants together with the Universal Declaration are collectively referred to as the International Bill of Human Rights ${ }^{14}$.

It is however important to remember that when the UN was founded in 1945, and when the UDHR first was elaborated, most parts of Asia and Africa was still under Western colonial rule. In the mid-1960: $\mathrm{s}$ the UN members had doubled in less than a decade and the AfroAsian states founded the largest voting bloc. Let's take a brief look at the Islamic countries, since the later discussion is concentrating on the dilemmas that the practical human rights implementation has led to in the Islamic parts of the world. In 1948 only five states of the

\footnotetext{
${ }^{13}$ Donally p 4

${ }^{14}$ Ibid p 9
} 
twenty-two actual members of the Arab State League existed (Egypt, Iraq, Lebanon, Saudi Arabia and Syria) and only seven out of today's forty-five members of the Islamic World Conference (adding Turkey and Iran) ${ }^{15}$. There was also a debate among the existing countries on whether approving the UDHR and thereby endorsing international human rights would be for Muslims to betray Islamic law and submit to Western cultural domination. In the end, when it came time to vote on the UDHR, Saudi-Arabia among the Muslim countries was alone in abstaining, joined only by South Africa and various East Bloc countries. ${ }^{16}$. The lack of other than western influence on the drafting of declaration of 1948 is often used as an argument by advocates of cultural relativism as an example of the ignorance of other standpoints than the western. The fact that some Muslim states actually took part in the drafting is on the other hand used as an argument for the opposite side. They point out that most states didn't protest during the making and did ratify not only the first two covenants, but also later conventions on human rights. Mayer does for example mean that it on this basis should be difficult to maintain that Muslim Countries are outsiders to the present system of international law ${ }^{17}$. Muslim countries can neither be said to have a poorer record of ratification than non-Muslim countries. Countries like Algeria, Egypt, Iran, and Iraq, on the contrary have favorable records in comparison to the USA. ${ }^{18}$

After the UN had established the standards for international human rights in the International Bill of Human Rights, it was followed by the quest of implementation and monitoring the implementation. Several conventions have followed upon the initial ones, some of them wellknown such as the CEDAW (Convention of Elimination of Discrimination against Women), the Convention against Torture and other Cruel, Inhuman or Degrading Treatment or Punishment, and the Convention on Rights of the Child. The development of human rights has also advanced on a non-governmental level, with the creation of NGOs such as Amnesty International and Human Rights Watch, putting pressure on governments and other potential human rights violators. They also produce alternative reports on the human rights situation in different countries. The existence of NGOs has been of great importance since the UN, despite monitoring, reports and now in later years even armed interventions, hasn't always been entirely successful. After the first two generations of rights; the political and civil, and

\footnotetext{
${ }^{15}$ Tabet Koraytem , Arabic Islamic Developments on Human Rights , Arab Law Quarterly 2001, Kluwer Law International Netherlands. p 256

${ }^{16}$ Mayer Ann Elizabeth, Islam and Human Rights - Politics and traditions, Westview Press 1999 Third edition, p 11

${ }^{17}$ Ibid p 10
} 
the economic and social rights, the development of a third and fourth generation has begun. With the focus changed to a more collective view, these are rights to for example peace and development. Third world countries often consider these rights more important to put focus on, then the political and civil rights that according to them gets all the attention. The same critic is also valid for the economic and social rights, and a changed focus to these rights is often mentioned as a way of increasing the interest of universal human rights at a grass-root level in the third world.

\section{Cultural relativism}

\subsection{Universality versus relativism}

The concept of human rights is based on the assumption that the human rights granted the individual are universal and therefore applicable to all individuals on the earth. This is a definition generally acknowledged by most states, at least those who are members of the UN. Thereby one can say that the universality of human rights, which refers to universal quality or global acceptance of the human rights idea, is established at least in theory. ${ }^{19}$ There is however an ongoing discussion, not only in Muslim countries, dealing with the universalism of human rights. Universalism of human rights would acquire a consensus on what these universal values are and how to interpret and apply human rights law.

For the believers in strict universalism, human rights must be the same in substance and application everywhere independently of cultural and religious aspects. They are often criticized by the advocates of cultural relativism for only seeing human rights through a "westernized" perspective, and assuming that the standards set by the western society are universal norms that can't be compromised in other cultural spheres. This is often argued by non-western societies as an attempt to impose western culture and values upon other cultures, in an almost neo-imperialistic way. ${ }^{20}$ The cultural relativists, on the other hand, are criticized for giving legitimization to regimes that oppress their people and violate human rights in the name of culture or religion. ${ }^{21}$ There are naturally different levels between the radical

\footnotetext{
${ }^{18}$ Mayer, p11

${ }^{19}$ Baderin Mashood A., Dialogue among civilizations as a paradigm for achieving universalism in international human rights - a case study with Islamic Law, Asia-Pacific Journal on Human Rights and the Law, Volume 2, Number 2, p 2

${ }^{20}$ Ibid

${ }^{21}$ Mayer, p 7
} 
universalism and radical relativism ${ }^{22}$, which are the two extremes. Radical universalism is the view that all values, including human rights, are in no way modified by history and culture. Moral views are on the contrary entirely universal and can be implemented identically anywhere independently of time and place. This is of course a highly unrealistic theory and in its pure form hard to find advocates for.

Radical relativism is relativism in its pure form, and presupposes that all moral values are determined by history, culture, economics and other social factors. This theory excludes all sorts of rights that everybody would be entitled to equally just as human beings.

Between these two extremes, that might be less practically functional, there are a variety of different relativist positions. These can roughly be divided into two ranges; strong relativism and weak relativism ${ }^{23}$. The former one has the emphasis on relativity, but leaves room for that some values can be universal. The latter reverses the emphasis and only allows secondary modifications on the universal rights on cultural basis.

\subsection{Cultural Diversity in a Western perspective}

Cultural Relativism originated in the West in the 1920s and 1930s, as a reaction to the arrogance of western attitudes towards other societies. Some western anthropologists felt there was a need of a counter-part to the beliefs that non-western societies were inferior to western societies, and that they would eventually evolve along similar lines. These ideas were a reaction to the spread of imperialism and evolutionism in the western world during the $19^{\text {th }}$ century. ${ }^{24}$ The relativist position is asserted to the empirical matter that the world contains an impressive diversity in views about right and wrong, linked to diverse underlying cultures. To proponents of relativism, instruments with a pretension to universality, such as the UN documents and conventions on human rights, may be seen as cultural imperialism attempting to universalize western values by making them the standard of what is right. The cultural relativist approach was first introduced in American anthropology by Franz Boas. The "Boasians" were skeptic about the universal laws of evolution, claiming that culture and not biology makes $\mathrm{us}^{25}$. Since the theory claimed that concepts like race and sex are cultural constructions, this became a rather attractive idea in the twentieth-century America, where racial problems were very prominent. The problem with a strictly relativist approach, where

\footnotetext{
${ }^{22}$ Donnelly , p 33

23 Ibid

${ }^{24}$ Dalacoura , p 24

${ }^{25}$ Steiner \& Alston, International Human Rights in Context, Oxford University Press 2000, Second Ed, p 379 (Adam Kuper; Culture: The anthropologist's approach. )
} 
all moral values are connected to a certain culture, is the potentiality of a culture where no support of human rights exists. Later theories such as Rawl's theory on “overlapping consensus" ${ }^{, 26}$, however claims that all cultures have some basic moral values in common. One can consequently find these cross-cultural universals and through them establish culturally sensitive rules on for example human rights. One example of a cross-cultural value is the universal aversion to death and injury, also called the principle of "retribution tied to proportionality". ${ }^{27}$ The problem with theories based on finding a lowest common denominator is that some basic rights would have to be sacrificed, such as the rights of women. But the cultural relativist think those are the downsides we have to live with since we don't have the right to decide for other cultures what values are right or wrong. Critics of the relativist view mean that this kind of thinking would undermine the whole idea of human rights. The doctrine of human rights should be a doctrine on a superior (or at least different) level and used to set the rules for how to deal with conflicts between other doctrines. ${ }^{28}$

\subsection{Islam and Cultural diversity}

In the debate on whether ethnical traditions, culture or religion have an impact on human rights, both in theory and practice, the Islamic culture is often referred to as being opposite the western ideas. Different reasons can be found for this focus. The fact that Islam is the third largest religion in the world, with more than a billion adherents, and is the fastest growing religion today is of course a contributing reason. If there should be major discrepancies between the attitude to human rights among Muslims in general, and the rights that have been declared as universal by the UN, it would mean that more than a fifth of humanity could question the legitimacy of these rules.

According to Bassam Tibi ${ }^{29}$, professor of International Relations at the University of Göttingen and author of several books about the clash of cultures between west and the Muslim world, another reason is that;

\footnotetext{
" Islamic and Western worldview are not only different, but also raise the same claims. A politicization of these worldviews and the related claims leads to a conflict that could result in a Clash of Civilizations"
}

\footnotetext{
${ }^{26}$ Jones Peter, Human Rights and Diverse Cultures , p 34

${ }^{27}$ Dalacoura , p 28

${ }^{28}$ Jones, p 41

${ }^{29}$ Tibi Bassam, Islam between Culture and Politics, 2001 Palgrave, p 214
} 
What Tibi refers to is that Islam raises claims to be universal, just like Christianity does. Other mayor civilizations such as Hinduism, Buddhism and Confucianism do not lay these claims and can therefore easier co-exist. Christianity has however, unlike Islam, undergone secularization in the course of the Renaissance and Enlightenment, but the western civilization has kept its universal outlook. Islam still bases the claims of universality on religion.

I think the focus on the relations between the Muslim world and the West as a source of conflict also is due to the picture that media and sometimes even politicians give of Islam as a religion closely connected with fundamentalism and after September $11^{\text {th }} 2001$ even terrorism. The fear created by a simplified view is a serious obstacle in any kind of dialogue between different cultures, and it also helps fundamentalist regimes to stay in power helped by anti-western currents. It further maintains a general belief that the two cultures stand much further apart then maybe they in reality do. The debate concerning human rights among Muslim scholars is of course as divided as that among western. On one side there are those who believe that human rights is a completely western idea, and any attempt to force it upon the non-western parts of the world is just a new form of colonization - an attempt to "westernize" the world. On the very opposite side there are scholars who have the will to go as far as to reinterpreting the religious rules to get closer to western human rights standards. Bassam Tibi is one of these reformists. He strongly advocates the importance of a dialogue between cultures, but stresses the importance for western human rights advocates to not compromise their opinion on what are basic human rights, and to keep trying to spread them to other cultures. The fact that human rights the way the UN states them might be an idea based in the western society doesn't mean they are wrong for other cultures. To start compromising the rights in themselves would, according to him, be crucial to the doctrine as $\operatorname{such}^{30}$.

Ahmed An-Na'im, another Muslim scholar who advocates Islamic reform, claims that the only way to resolve the conflict between Islam and the theory of human rights is by a new interpretation of Islam $^{31}$.

Both of these scholars are however strongly influenced by western ideas and live in exile in the West. Although they are important names in the human rights discourse in the West, their influence in the Muslim world is very small. The problem with a reinterpretation of Islam,

\footnotetext{
${ }^{30}$ Tibi Bassam ,Islam between Culture and Politics

${ }^{31}$ Tergel Alf, Human Rights in Cultural and Religious Traditions, Acta Universitatis Upsaliensis, Uppsala 1998 p 94
} 
which maybe is to be seen as the strongest possibility to conciliate Islam with modern realities, is that it seeks to reform the scriptural Islam as comprised in Sharía, rather than the popular Islam dominating most parts of the Islamic world. This Islam is more based in cultural behavior and tradition then actual scripture ${ }^{32}$. Reinterpretation also meets strong resistance among many Muslims, some even claiming it to be blasphemy.

In Muslim countries the development in later years has not been in the direction towards secularization or reformism. Instead the fundamentalist movements have grown stronger in many places, and the call for a "re-islamisation" has gained increased support. This process probably is due to different reasons, but it's difficult to not see the connection between this and the anti-western currents that have been the consequence of among other things the way the conflict in Palestine has been handled, and the treatment of Iraq and Afghanistan in the USA-led war on terrorism, in which one can may question the use (or abuse..) of International Law. Trying to find out the opinions on cultural relativism among conservative Muslim scholars is a difficult task. Much of the literature available is written by Muslims working at European or American universities, and doesn't give a just picture of a general stand of the Islamic scholars. On the other hand, documents by not westerly-educated Muslims are arguing from such a different perspective from what we are used to that they are hard to use in a comparative study with a legal perspective.

Abu'l A'la Mawdudi, a conservative Sunni Muslim from Pakistan, is internationally prominent and was active in Pakistani politics, leading a political group committed to reinstate an Islamic state. Mawdudi, who was a firm critic to the Western society and culture, died in 1979. Having written much about the application of Islam to contemporary problems, he is still often quoted in the debate on Islam and human right, and his work has been widely translated. He basically considers the Western culture as decadent and inferior to the Islamic culture. ${ }^{33}$ Universal human rights, as established by the UN, are according to him a Western idea not needed in an Islamic society. The perfect Islamic society, which should be what all good Muslims strive for, does automatically give humans all the liberty and freedom they need. His document "Human Rights in Islam", which will be included in my later analyze, starts out with his explanation of the Western approach:

\footnotetext{
${ }^{32}$ Abdelmoula Adam M, The Fundamentalistic agenda for human rights - The Sudan and Algeri, Arab Studies Quarterly, Winter 96, Vol 18 issue 1, p2.

${ }^{33}$ Tergel p 90
} 


\begin{abstract}
"The people in the West have the habit of attributing every good thing to themselves and try to prove that it is because of them that the world got this blessing, otherwise the world was steeped in ignorance and completely unaware of all these benefits."
\end{abstract}

The Islamic approach, he continues, is that all human rights necessary are granted by God and as such they can't be withdrawn by a legislative assembly, as the rights granted by man can. He also claims that Western human rights are based on philosophical concepts, without any sanctions behind them.

In Iran, cultural relativism has been a popular way of justifying a record of poor adherence to international human rights standards. In 1995, the Iranian ayatollah ${ }^{34}$ Ali Khamenei, the supreme leader of the Islamic Republic, urged his foreign affairs functionaries to reject the Western notion of human rights. He claimed that they were part of a civilization coming to its end, and that the system would be replaced by a universalism based on Islam:

\footnotetext{
"Today the Islamic system is questioning the identity, goal and capability of the Western system, and the most superior Western thinkers are gradually realizing the tediousness of the Western system. Thus, the civilization that began with the Renaissance is coming close to its finale. Human beings today are searching for a substitute for the Western system, and the inclination toward Islam in the United States, Europe and Africa emanates from this situation." 35
}

\begin{abstract}
Also President Khatami has expressed similar opinions, although he was elected being a popular reformist.
\end{abstract}

From the fundamentalist movements it is hard to find any theoretical writings. This is possibly a chosen strategy for these movements, with the aim to give the leaders a stronger position, leaving the members under their authority. ${ }^{36}$ Hassan al-Turabi, leader of the National Islamic Front in Sudan has however written about the ideology of his movement. He openly rejects human rights as being a product of positivist and materialist Western jurisprudence. He talks about a utopian Islamic society where loyalty to God is going to free the people from all

\footnotetext{
${ }^{34}$ Khomeini is sometimes referred to as ayatollah, and other times as Imam. Ayatollah is an honorific title for high-ranking Shi' ite authorities in Iran, that came into being only this century. After the revolution in -79 he himself gave up using the title and adopted the title of Imam. The word Imam has several different meanings in Islam. The leader of the congregational prayer is an Iman, but it is also the title used for the founders of the madhahab (the Sunna schools). For the Shi'ites the word Imam has a special significance of an intercessor, unique and predestined to the age that has to be recognized and followed. The so called Twelve-Imam Shi' ites believe in a hidden Imam will return - Khomeini not being him. (The concise encyclopedia of Islam, Cyril Glassé, Revised ed. 2001, Stacey International, London )

${ }^{35}$ Afshari Reza, Human Rights in Iran -the abuse of Cultural Relativism, University of Pennsylvania Press,Philadelphia, p 4
} 
chains of materialism. In such a society invoking freedoms or rights could never be a problem.

Cultural relativism, in the discourse of human rights in the Islamic world, is often used as an argument for compromising the existing rules of human rights, or even creating a new set of rules based in the moral values of the Islamic religion. Examples of that are the different Islamic human right documents that I later will describe and analyze.

\section{Islam and Sharía}

Before starting to try to compare the Islamic law with international human rights law, it is essential to try to point out and explain some of the basic differences between Islam as a religion, and for example Christianity. I will also briefly describe the history of Muslim culture and politics. In his book "Islam in the world"37 Malise Ruthven describes the essential difference between Christianity and Islam, as while the former is primarily the religion of love, Islam is rather the religion of justice. This should of course not be taken literally; Christians are of course not generally more loving than Muslims and Muslims not more just than others are. But Islam sets up rules for everyday life and behavior in a way Christianity doesn't. With the Sharía, Islam has a legal system closely linked to religion - a legal system of purely divine source, not to be altered by man. To understand how Islam can be so closely connected to society and politics still today, one needs to consider the nature of the religion during its early years of formation.

\subsection{The history of Islam}

\subsubsection{The Prophet}

The history of Islam starts with Muhammad ibn `Abdullah of the Banu Hashim of Quraish, who around 570 a c was born into one of Makka's best families. Not much is known about his early years. What we do know is that his father was a merchant who died before Muhammad was born. According to his family's customs he spent his first years with a Bedouin tribe. The pure air of the desert was considered to be good for the health of children. This made him familiar with the special elliptical quality of speech which characterizes the style of the Qur'an. When Muhammad was six years old his mother Amina died, leaving Muhammad an orphan. He was then taken into the household of his paternal Uncle Abu Talib. At an early age

\footnotetext{
${ }^{36}$ Abdelmoula, p 3

${ }^{37}$ Ruthven Malise, Islam in the World, Oxford Press 1999, Second edition p 219
} 
Muhammad started working in the merchant caravan of Makka. He was a very serious and respected young man and earned the nickname al-Amin, the trusty one. At twenty-five he got married to a rich Quarishi widow, Khadija bint Khuwailid, who according to tradition was about forty and already the mother of several children. Despite this, she is said to have borne him four daughters and several sons. All his sons died in infancy. They stayed married for fifteen years and appear to have had a happy marriage, even though the loss of all sons must have been a considerable blow in a society where a man's prestige to some extent depended on the number of his sons. Muhammad remained monogamous in his relation to Khadija, something very rare in a time where temporary marriages were not only permissible but socially accepted. After Khadijas death he did however, according to tradition, marry eleven or even more women. He was said to have an exception from God from the rule in the Qur'an in which four wives per man is the upper limit. Most of his marriages had political significance, such as enhancing the alliance with a Bedouin tribe by marrying a daughter of the chief. In his forties Muhammad began spending an increasing amount of time in solitary contemplation in a cave in the hill of Hira, a few miles north of Makka. It was in this cave he first received his "call" to prophethood, and the first of the revelations on what by the Muslims is called the Night of Power, the night of 26-7 Ramadan. An angel sent by God said to Muhammad: "Read!", to which he twice answered "What shall I read?". Finally the words of what by a great majority of scholars are regarded as the first Qur'anic revelation came to him;

Read in the name of thy Sustainer who has created -

Created man out of a germ-cell

Read, for thy Sustainer is the Most Bountiful One

Who has taught (man) the use of pen-

Taught man what he did not know! (The Qur'an 96:1-5)

Muhammad kept receiving divine revelations during a period of twenty-two years (610-632), which later where collected and written down in the Qur'an, the Holy Scripture of Islam. Muhammad fought for almost ten years to spread the word of God in Makka. It became increasingly harder, especially after the death of his protector Abu Talib, in 619. When the resistance turned from verbal harassment and mockery to physical persecution, Muhammad and two hundred of his followers emigrated to Madina. This migration; the so-called Hijra, was to become an important turning point in the history of Islam. The Umma, the Islamic community, was founded during the Madina-period and Islam took a political form. The Hijra 
took place in 622 and the Muslims chose to start their calendar from there and not from the birth of Muhammad, or the date of the first revelation. One important change from then on was that Muhammad not only held the role of a Prophet. He also became a political leader for the religious-political community of Madina. The Hijra was followed by years of fighting between the Muslims of Madina and Makka, where the Muslims step by step grew stronger due to Muhammad's political and diplomatic skills.

At his death in 632, Muhammad had not only managed to conquer Makka, but also to unit all of Arabia under the banner of Islam.

\subsubsection{The "Rightly Guided" caliphs}

The years between 632 and 661 are known as the era of the "Rightly Guided"- caliphs. This was a very turbulent time for the still young Muslim State. Non-Muslims may find it astonishing that this time of continuous conquest, violence and civil war is referred to by Muslims as a golden age. It was during this time the foundation of the new religion was laid down, both normatively and geographically. It is also from this era that all sources of the Sharía derive, and all Islamic renewal and reform, traditional as well as modernistic, has to find its references there.

The first caliph Abu Bakr was the father of Muhammad's favorite wife Aisha and one of the first converts to Islam. He had been chosen by the Prophet to lead the pilgrimage of 631 and also to act as Imam (or leader of the congregational prayer) during his final illness. He seems to have been the obvious choice as Muhammad's successor, but according to most Sunni Muslims Muhammad himself died without appointing anyone to take over his position as leader. Abu Bakr managed to keep the Islamic State together, despite the problems in the repercussions of Muhammad's death. Among other things some of the Bedouin tribes wanted to break free, claiming that their alliances with the Islamic states where political pacts with the Prophet personally. Abu Bakr reigned for only two years, and before his death in 634 he had designated Umar ibn al-Khattab his successor. During the reign of Umar the sporadic raids against revolting tribes turned into a full-scale war of conquest. At the time of his death in 644 the Arab raiders where reaching as far as Barqa in the West, to the central Iranian highlands in the East. Umar was murdered by a Persian captive, and as he lay dying he appointed a committee of six men of the Quraishis to choose his successor. The leading candidates where Uthman ibn 'Affan of the Umayyad clan, husband to one of the prophet's daughters and an early convert and companion of Muhammad, and Ali the prophets first 
cousin and husband of his daughter Fatima. Ali had been raised in the prophet's household and had been closer to him than any other male relative. Uthman was chosen, probably because the committee wanted to make sure that the conquering of Umar would continue. Ali had already voiced some opinions against these policies, which he wasn't convinced was in accordance with the Qur'an. Uthman turned out to be a less talented leader, lacking some of his predecessor authority and political skills. The period leading to his death by murder in 656 was a turbulent time, where the Islamic State faced its first major internal crises. His death was followed by five years of civil war known as the first fitna.

Ali did however become the last of the four "Rightly Guided"-caliphs. He was a charismatic and energetic person, and had the support of those who had believed the caliphate should have stayed within the family of the prophet after his death. These Muslims, who later would be called the Shia-muslim (shiat-u-Ali, Ali's Party), were very content when Ali finally received what was rightly his to start with. Their satisfaction and prospects didn't last long. During the six years Ali was caliph, two major civil wars took place. The first opposition movement was led by Aisha, Muhammad's widow. With Ali's death in 661, the era of the rightly guided caliphs ended.

Muhammad's strength, both as a prophet and a statesman, and the way in how Islam was not just a religion but also a state-like community in it's early years, are probably parts of the reason to why Islam more than maybe any other religion claim to regulate all parts of the life of it's adherents - including legal and political aspects. The Muslims try to find their guidance in life in the example of Muhammad ${ }^{38}$. When the Qur'an, Muhammad's revelations, does not give an answer on how to act in a certain situation, the answer should be searched in the tradition and life of the prophet. Among the early Muslim scholars, law was not an independent, empirical study, but rather the practical aspect of the religious and social preaching of Mohammad. Little or no distinction was made between legal and religious terminology.

\footnotetext{
${ }^{38}$ Esposito John L. Islam - den raka vägen, , Studentlitteratur 2001, p 35
} 


\subsection{Islamic law 39}

\subsubsection{Primary sources}

When referring to "Islamic law", we usually mean what in Arabic is called the Sharia. Sharía means "the right way", and is a religiously based system of rules with its roots in the Qur'an , the Muslim's holy book. The Sharía also includes the Sunna, a collection of the traditions of Muhammad. The Qur'an and the Sunna are accepted as infallible sources, since they are directly derived from the prophet's words and actions.

\subsubsection{The Qur'an}

The Qur'an is considered to be based on divine revelation of God's word, made by the Angel Gabriel to Muhammad between the years 610 and 632. The Qur'anic texts were compiled a couple of years after the death of Muhammad. Since the Muslims believe the Qur'an to be divine, it is the highest and most important source of Islamic law. The Qur'an however does not contain many statements that constitute rules of law capable of direct application. Out of the Qur'an's about 6200 verses, which are divided in 114 chapters in 30 main parts, only about three percent are dealing with questions that from our Western point of view are of legal nature. There are about seventy verses regulating matters of family law, about seventy on other civil law issues, thirty verses on penal law, twenty on public and taxation law and finally about twenty that has some kind of relevance in the field of international law.

\subsubsection{The Sunna}

The second most important source of law in the Sharía is called the Sunna. The Sunna is the tradition of Mohammad, written down in the so-called Hadith by some Muslim writers in the 7th century. The Hadith is said to have its origin in stories about the prophet's actions and the traditions of his followers. Using the Hadith as a starting point, one tries to imagine how the prophet would have solved a certain problem. The Hadith continued to develop during the

\footnotetext{
${ }^{39}$ Sources for basic information about Islamic law;

K. Zweigert \& H. Kötz, An Introduction to Comparative law, Third edition, , 1998 Oxford University Press Bogdan Michael, Komparativ Rättskunskap, , 1996 Nordsteds Juridik

Ruthven Malise, Islam in the world, second edition 2000, Oxford University Press, NY

Nordberg Michael, Profetens folk, Tidens förlag, Stockholm 1988

H.A.R Gibb "The Shari'a" (www.answering-islam.org)

Wikipedia Encyclopedia (www.wikipedia.org.wiki)
} 
time of the first four caliphs. After the death of the fourth caliph Ali in 661, no one was considered to have any authoritative right of interpretation of Hadith or Sunna.

In the 8th century, four main Sunni schools of jurisprudence established themselves in different parts of the Islamic world, the so-called madhahibs (sing. madhhab), the Arabic expression for "ways":

The Hanafi in the Near and Middle East was founded by Abu Hanifa (d. 767) and developed in Iraq. It is based on the Hadith, but have rather wide possibilities for interpretation based on "common sense" and analogies. The Hanafi School was the official doctrine of the Abbasid caliphate.

The Maliki in North, West and Central Africa is considered of many to be the most liberal school. It has its roots in Medina and the Syrian schools of interpretation and was founded by Malik ibn Abas (d. 795). It attaches great weight to vox populi, the living tradition, rather than what formally is considered the Hadith. In that way the link between law and society is kept alive. Among other things, the Maliki school gives women more individual rights than the others. Countries with the intention to change their laws in a liberal way often seek their support in this school.

The Shafi' $i$ in east Africa, Malaysia and Indonesia, was founded by the famous theorist Muhammad al Shafi'i (Egypt d. 820), and is a strictly formalistic way of interpreting the Sunna. According al Shafi'i any tradition that isn't directly traceable back to the prophet himself is inadmissible. To be able to know exactly how to solve a problem the way Mohammad did, al Shafi'i developed a complicated system of "links of tradition" so called isnâd. The isnads have different values, but all have to be satisfactory to not break the chain back to the tradition of the prophet. Every link has to be an approved intermediary of the Islamic tradition, such as a companion of Muhammad or some other approved legal authority. Hadiths with the first link unknown, so called mursal isnâd, are permitted in for example Malaki, but not in the Shafi'i.

These three where the three original Sunni schools of interpretation, and in spite of their formal differences and divergences in details, they grew into agreement on more important matters. They all in practice recognized the same sources; Qur'an, Sunna, Ijima and some form of analogical reason. They all recognize each other's systems as equally orthodox. These three schools where followed by several other schools, often developed as a strong traditionalist reaction to the speculative "innovations" of the previous schools ${ }^{40}$. Most of them

\footnotetext{
${ }^{40}$ H.A.R Gibb "The Shari'a" (www.answering-islam.org)
} 
never gained a wide following, and only one is recognized by the other three as the fourth orthodox school:

The Hanbali-school, founded by the Baghdad doctor Ahmad ibn Hanbal. It had strong following in Iraq and Syria until the Ottoman conquest. It was revived (under the name of Wahhabi) in Central Arabia, and is nowadays dominant in Saudi-Arabia. It developed from the Shafi'i school, and is often referred to as orthodox extremism ${ }^{41}$.

There also exists two shi' istic schools of interpretation. Only $8 \%$ of the world's Muslims are Shi'a-muslims, most of them resident in Iran. The division between Sunni and Shi'a Muslims is the one most familiar to us in the non-Muslim parts of the world. The division was made after the death of Ali, the last of the rightly guided caliphs. The Shi'a Muslims puts less weight at the Hadith. They do acknowledge it, but the interpretation of the Hadith must be made by an authorized Imam ${ }^{42}$. The Shi'a Muslims believe in the return of the twelfths Imam. It is however important to note that Khomeini and his successors are not this kind of Imams, even if they often in Western media are mistaken for that ${ }^{43}$. The religious leader of the country does however have a very strong position in interpreting the Sharía.

\subsubsection{Secondary Sources of Law.}

Neither the Qur'an nor the Sunna offers a system of legal provisions, they only supplies the material from which a system could be constructed. In the construction of such a system a science of interpretation was created. The science of fiqh, the Islamic jurisprudence, has apart from the Qur'an and the Sunna two other roots (usul);

Ijima - consensus among schoolar jurists, opinio juris. Ijima as a principle was enshrined in the Hadith in which the prophet is said to have declared that "never will God make my community agree upon a wrong course" 44

Quias - systematic analogical reasoning. This is the technique in which legal experts sought to incorporate new situations within the divine system

There is also a third source, which sometimes is mentioned as a part of the Sharía and at other times not accepted:

Itjihad - independent legal reasoning, is by many reformists seen as the only way to reinterpret Islamic law to better adjust to modern ideas and society. Conservatives does

\footnotetext{
${ }^{41}$ Theutenberg Bo J, Folkrätt och säkerhetspolitik, Nordstedt 1986, p562

${ }^{42}$ Theutenberg, p562

43 see footnote 34
} 
however claim that the "gate to Itjihad", and thereby all possibility of re-interpretation, was closed after the tenth century. ${ }^{45}$

The science of fiqh started in the second century after Hijrah, when the Islamic state expanded and faced several issues which were not explicitly covered in the Qur'an or the Sunna. Rulings based on the unanimity of Muslim scholars and direct analogy are generally considered to be binding. The four Sunni schools of thought, Hanafi, Maliki, Shafi'i and Hanbali, are identical in approximately $75 \%$ of their legal conclusions. Variances in the remaining questions are traceable to methodological differences in understanding or authentication of the primary textual evidence. Differing viewpoints sometimes exist even within a single school of thought.

The Sharía has never been erected into a formal code, but it has been said to be a discussion about the duties of Muslims. Human actions are graded according to a scale of moral valuation. There are five main categories ${ }^{46}$ :

1. Fard, obligatory acts, omission of which constitutes a sin.

2. Haram, forbidden acts, commission of which constitutes a sin.

3. Mandub, recommended acts, where there is merit in doing them but no sin in omission.

4. Makruh, undesirable acts, where there is merit in abstaining from but no sin in commission.

5. Mubah, unspecified acts, neither meritorious nor sinful, whether omitted or committed. Some actions lead to punishment according to Islamic law. These so called hudúd-crimes are given much attention in the Western media, since the punishments prescribed for them in the Qur'an are criticized as being cruel and inhuman. The hudúd crimes include theft and adultery, and are punished by flogging, cutting of hands (in the case of theft) or in some case death. The hudúd also include gambling and drinking alcohol, but for these crimes no punishment is settled in the Qur'an, and they have been judged differently in various times and places.

In practice many countries in the Middle East and North Africa maintain a dual system of secular courts and religious courts. The religious courts mainly regulate marriage and

\footnotetext{
${ }^{44}$ Ruthven $\mathrm{p} 139$

${ }^{45}$ Ibid p 143

${ }^{46}$ Ruthven, p149
} 
inheritance. Saudi Arabia and Iran maintain religious courts for all aspects of jurisprudence. Sharía is also used in Sudan and Libya, and some states in northern Nigeria have reintroduced Sharía courts.

I will later get back to the more specific Sharía-rules that constitutes a problem in the debate of human rights, and describe in what manner they are opposed to some of the values set down as international law in the different UN documents on human rights.

\section{Regional Human Rights development in theory}

Before discussing the theoretical difficulties when dealing with human rights from an Islamic perspective, I would like to emphasize that the comparison is based on a generalized idea of a Sharia-based, non-secularized system. Most Muslim countries have laws that in various ways are partly secularized, but since the societies are strongly influenced by the religious rules, I find it important to compare from a perspective of principle.

\subsection{The Theocentric versus the Anthropocentric difference}

One fundamental difference between Islamic and positive western law is that the former is based on a theocentric approach. Theocentric means having God as the central point of focus, while anthropocentric means putting man in that place. The former is consequently a religious perspective, while the later is a secular approach. In a theocentric perspective God is the origin of all human life, and therefore also the original granter of all human rights ${ }^{47}$. Since God is omnipotent, he knows what human beings know not, and human knowledge is limited (Qur'an 3:66). Therefore there is no reason for man to make laws to protect the individual; the divine law of God is perfected in the best interest of the individual and the community. International human rights law follows the anthropocentric approach. Being based on a secular philosophy, it grants the individual rights on the sole base of its humanity and makes no direct reference to God. Although freedom of religion is recognized as a human right, religion is not considered the basis for human rights. The "non-reference" to God in

\footnotetext{
${ }^{47}$ Baderin Mashood A., Dialogue among civilizations as a paradigm for achieving universalism in international human rights - a case study with Islamic Law , Asia-Pacific Journal on Human Rights and the Law, Volume 2, Number 2, p22
} 
international human rights documents has raised the question in the debate among Muslims, whether this makes the documents themselves irrelevant and non-binding under Islamic law. ${ }^{48}$ There has been a tendency among Islamists to try to write off the UDHR as being incompatible with the principles of Islamic law on these premises. Those opposed to this view claim, that even though no direct reference to God is made, one has to see to the essence of the document and judge from the content whether or not it is compatible with Islamic law. Or as Riffat Hassan stated;

\footnotetext{
"Reference to God does not necessarily make sacred, nor does non-reference to God necessarily make profane any human document....a document such as the Universal Declaration of Human Rights which, though "secular" in terminology, seems to me more "religious" in essence than many "fatwas" given by Muslims and other religious authorities and agencies" $" 49$
}

The Muslims have not been the only ones to advocate a reference to God concerning human rights. When drafting the UDHR the delegation of Brazil asked to conclude a reference to God in the second part of the first article which says that;

"All human beings are born equal in dignity and rights. (Created by God in his own image and resemblance) They are endowed with reason and conscience and should act towards one another in a spirit of brotherhood."

China among others protested against this, and no reference was made. In many Islamic documents on human rights, which I will get back to later, this kind of reference is often made. The theocratic starting-point doesn't necessarily constitute an obstacle in granting individual human rights. The rights we now consider universal do partly have their basis in an idea of natural law, which as I see it can be hard to theoretically explain and justify without some higher power setting the rules. A system where the laws are set by an omnipotent God not to be altered by man, is however inflexible when trying to compromise with other legal systems.

\footnotetext{
${ }^{48}$ Baderin, p23

${ }^{49}$ Hassan Riffat, On Human Rights and the Qur'anic Perspective, Swidler A (ed) Human Rights in Religious Traditions, NY 1982, Pilgrim Press p 52

${ }^{50}$ The phrase in parenthesis being the addition Brazil suggested.
} 


\subsection{Problem areas in Islamic Human Rights Documents}

Before the analyze of the Islamic human rights documents I've chosen as relevant, I find it necessary to shortly comment on the areas in which the implementation of our western ideas find the strongest theoretical resistance. I do this since it is my opinion that in most fields there isn't, at least in theory, really a discrepancy between the universal human rights as formulated in the UN documents, and the rights accepted as stated by God in the Qu'ran and other parts of the Sharía. Islam, in difference to many other religions, on the contrary has a rather well developed system of rights formulated in its Holy Scriptures. ${ }^{51}$ There are however some areas in which tradition and religious standards makes it almost impossible to compromise between the Western and the Islamic views on human rights. I will first describe these areas, and they will later be the main focus in my analysis of the Islamic human rights documents.

\subsubsection{Unequality between the sexes}

The problem area most frequently described in Western media, probably since the discrepancies here are obvious and often creates a problem among Muslims integrated in secularized societies, is the rights of Muslim women. Islamic societies are often accused of extended discrimination against women. In extreme cases, such as the Taliban regime in Afghanistan, the oppression of women has been systematic and has taken the development in equality back to a pre-historic level in the name of Islam. The history of Islam is however not one of degrading treatment of women. On the contrary the Qur'an devotes considerable attention to women. Islam meant a significant improvement of the conditions for women in pre-historic Arabia, enhancing their rights and status. The Qur'an introduced reforms such as the prohibition of female infanticide, which earlier was a considerable problem. It permitted women to inherit, restricted the practice of polygamy and gave women ownership of the dowry, which earlier had been paid to the bride's father. Not only did the Qur'an abolish previous traditions discriminating women, but it also conferred to women in the seventh century rights that women in the West didn't obtain until recently ${ }^{52}$. Muslim women already at Mohammed's time enjoyed full legal personality, could own and manage property and

\footnotetext{
${ }^{51}$ Except for the basic rights, such as the right to life and rights to justice, it is interesting to note the Sharia also includes an elaborate collection of rules on how to treat civilians and soldiers of the enemy at war, very similar to those based on the thoughts of Grotius who much later became the International Law now recognized.
} 
could according to some interpretations of the Sharia achieve divorce on relatively liberal grounds. Contemporary Muslim feminist and reformists often argues that it isn't reasonable that a religion that in the beginning aimed to remove the disabilities women suffered in prehistoric Arabia, in later interpretation and traditions has been used as a mean to keep women in an inferior status. ${ }^{53}$ Both the Qur'an and the other parts of the Sharía are however written for a society characterized by a patriarchal family structure, where men and women had different roles and the man in his capacity of provider had a superior status. This standpoint can be found in many religions, Christianity of course included. The difference with Islam is that since the Sharía takes an essential part in the legal systems of a number of Islamic states today (at least in family law), rules which differentiates between the rights of men and women may still be enforced. How women's rights are dealt with of course depends on how the Sharía is interpreted. The following examples are simply verses and rules that may lead to an unequal treatment of women, and often are used in argumentation by conservative Muslims who claim that an inferior position for women is a natural part of the Islamic community (although not necessarily due to disrespect and maltreatment, since this difference in rights often is defended as being in the best interest of the women and her chastity..) The verse of Sharía most often used to argue the inferiority of women is $2: 228$ : "[women] have rights similar to those [of men] over them in kindness, and men are a degree above them.. ${ }^{, 54}$ In verse 4:34 the male control is further connected to the fact that he is the provider of the family and consequently has financial power over the married woman. She shall therefore obey him: "Men are in charge of women, because Allah has made the one of them to excel the other, and because they [the men] spend of their property [for the support of women]."

While these verses are simply used by conservatives to state the difference between the genders in general, there are more concrete rules in the Qura'n in which the rights of women are not equal to those of men. Women are for example only entitled to half the inheritance of their brothers (4:11). In the case of business agreements, two female witnesses equals one male (2:282). There are even statements permitting the husband to beat his wife in case of her disobedience (4:34).

The right of women to obtain a divorce from her husband is far more limited than that of a man. The only way according to Sharía, in which women have the right to a divorce is the so

\footnotetext{
${ }^{52}$ Mayer p 98

${ }^{53}$ Ibid p 98

${ }^{54}$ Ibid p 107

${ }^{55}$ Mayer, p 111
} 
called Khul', where the consent of the husband is needed, or the dissolution is agreed upon by a judge according to Sharía rules which puts up high requirements for the women to meet. The right to marry is also more limited for women, since they're only allowed to marry a Muslim man, while the man has the right to marry a woman of any of the religions of the book. Men also have the right to marry up to four women, as long as he can treat them all equally. Another discrepancy is found in the rules on adultery, regulated at two separate places in the Qura'n (4:15 and 24:2). The later of the two stipulates the same punishment for women and men in case of adultery (flogging), while according to some interpretations of 4:15 death penalty can be imposed for women if four witnesses who has witnessed the act of adultery can be produced.

Conservatives often use the general statements on female inferiority and women's responsibility to care for children and home, to justify the banning of women from for example getting a job outside the home, driving, and in some traditions even leaving the house without the consent of her husband. The same arguments are used to limit women's possibilities to get higher education, and in lower education segregated schools are called for. Baring women from political participation in the name of Islam is not unusual, but the grounds for this in the Sharía, as in many other cases of discrimination, is being continuously debated.

Another debated issue in is the hijab (veil or barrier). The hijab is mentioned in no less than seven places in the Qura'n, and is mostly referring to the barrier between deity and mortals (42:51) and between wrongdoers and the righteous $(7: 46,41: 5)^{56}$. Hijab is nowadays however used as the name of the Islamic dress-code, enforced in for example Iran, which doesn't allow women to show any skin except their face and hands. This meaning of the Hijab is probably referring to the passages in the Qura'n according to which the wife's of Muhammad were supposed to live secluded, and only were allowed to talk to male visitors from behind a screen (33:53). While conservatives argue this kind of seclusion to apply to all women, liberals claim that this only was a rule for the prophet's wives ${ }^{57}$. Though female clothing isn't mentioned in any of the verses where Hijab is contained, there are other verses treating how women should be dressed (ex 33:59 and 24:30-31). It is stated, among other things, that women shall cover themselves up in different ways, to avoid being molested and only display their "charms" to their husbands. One may discuss whether the restrictions on female clothing constitute a restriction of their human rights. But to many women, for example in Iran where they before

\footnotetext{
${ }^{56}$ Ruthven, p 158

${ }^{57}$ Ibid, p 159
} 
the Islamization lived a secularized life, the new dress codes meant a considerable restriction in their freedom of conscience and expression, and it is also a strong symbol for the unequal treatment of women. ${ }^{58}$

Equality between the sexes is undoubtedly one of the most complicated areas in the Muslim human rights discussion, and even the most liberal forces agree that the only way to have an internationally accepted standard of rights of women without secularization would be a severe re-interpretation of the Qura'n. ${ }^{59}$

\subsubsection{Rights of non-Muslim minorities}

Religious minorities in Islam can be separated into two categories; people of the book - ahl al-Kitáb (Jews, Christians and Zoroastrians) and other religious minorities. The people of the book have always been allowed to keep their religion without interference under a certain protection, so called dhimmi, as long as they pay a poll tax called jizya and "subdues" $(9: 29)^{60}$. In pre-modern times that was a pretty tolerant policy compared to that of other religions. In pre-modern Sharía doctrine, the non-Muslim believers that not were ahl al-Kitáb, were considered polytheists or unbelievers who had to embrace Islam or die. In practice, as Islam expanded eastwards, the pre-modern doctrines had to be adjusted and Muslim learned to coexist with Hindus and other polytheists. ${ }^{61}$ According to some interpretation of Islam, non-Muslims may be excluded from high political positions and not allowed to serve in the military. The exclusion from the military does however have its foundation in the idea that no non-Muslim could be expected to fight the religious wars, which took place in the early days of Islam. In some ways it may seem hard for non-Muslims to achieve exactly the same rights as Muslims in an Islamic society, if traditional Sharía rules where to be applied. Therefore the rights of non-Muslim are often mentioned as a problem area in the human rights discourse. Islam might be rather tolerant as a religion, compared to Christianity or Judaism when it comes to relating to other religions, but a non-secularized state will never be as open to religious freedom as a secularized one. Fact remains that the statue of dhimmas still is not exactly that of Muslims, who are the only full citizens in an Islamic state. ${ }^{62}$

\footnotetext{
${ }^{58}$ Afshari, p 571

${ }^{59}$ Dalacoura, p 47

${ }^{60}$ Mayer, p 137

${ }^{61}$ Ibid, p 134
} 


\subsubsection{Freedom of religion}

The issue with freedom of religion is a problem not as much related to the non-Muslim minorities in the Islamic states, but to the Muslims who may want to convert to another religion, or who gets accused of apostasy. Sharía prohibits conversion from Islam to any other religion ${ }^{63}$. The problem with the Sharía rules on apostasy also has effects on the freedom of expression to a large extent, since expressing a view that the authorities find contravenes with their official view of Islam can lead to diverse punishments.

Under the interpretations of the pre-modern jurists, apostates were to be punished by death if they didn't repent and return to Islam. Blasphemy was also a punishable crime. Still today there are examples of fundamentalists using these interpretations, the most famous example is probably the late Ayatollah Khomeini's fatwa sentencing the author Salman Rushdhie to death $^{64}$. There are many contemporary liberal Muslims who claim that there is no direct statement stipulating earthly punishment for apostasy, and that it is against the principle of tolerance which figures prominently in the Islam value system to punish apostasy ${ }^{65}$. The verse $2: 256$ in the Qura'n stating "there is no compulsion in religion" is often quoted to support this and also 18:29, in which God instructed the Prophet to "Say, the truth is from you Lord. Let him who will believe, and let him who will reject it..".

If the Sharía rules on apostasy, and those which prohibits talking about the Prophet in a disparaging way are applied in an Islamic state, this constitutes a restriction in the unqualified rights to freedom of religion and also freedom of expression called for in the UDHR and other international documents on human rights.

\subsection{Islamic documents on Human Rights}

International Human Rights Law relies on national law and institutions for its implementation. It is also often also discussed and regulated on a regional level, with the European Convention on Human Rights and its system with an independent Court as maybe the most accomplished one. In the Muslim parts of the world (mainly Arabic-Islamic, since that is our focus), there has of course also been regional work done in the field of human rights. Several documents

\footnotetext{
${ }^{62}$ An-Na'im A. A, Human Rights in the Muslim World, 1990 (from International Human Rights in a Context, p 392)

${ }^{63}$ Dalacoura, p 47

${ }^{64}$ An-Naim (Steiner \& Alston), p 392

${ }^{65}$ for ex An-Naim, p 396
} 
with the aim of adapting the universal standards of human rights to the Islamic culture have been produced by different organizations and through governmental cooperation.

Since I've chosen to compare these regional documents against the UN standards for human rights, such as they are formulated in the International Bill of Human Rights, it is relevant to know to what extent the Islamic countries are parties to the these two covenants (the CCPR International Covenant on Civil and Political Rights and the CESCR - International Covenant on Economic, Social and Cultural Rights). The Arab League, which I will focus on later in the chapter about regional human rights development in practice, has 22 members ${ }^{66}$. Out of these Saudi Arabia, the United Arab Emirate and Bahrain, Mauretania, Oman and Quatar haven't ratified the covenants. The Organization of the Islamic Conference (OIC), an organization where all the states that consider themselves Islamic are members, has 57 members including those of the Arab League. Except those already mentioned from the Arab League that haven't ratified the two Covenants, Brunei, Comoros, Indonesia, Malaysia, the Maldives and Pakistan have also declined being parties to them. The countries in the OIC represent about $30 \%$ of the member states of the UN. They also represent $30 \%$ of the states that hasn't ratified any of the Covenants. One can however note that out of the remaining $70 \%$ that haven't ratified, almost $3 / 4$ are small island-states in either the Caribbean or Pacific Ocean with between ten and twohundred thousand inhabitants. The percentage of states without ratifications is slightly higher within the Arab League (27\%) and the OIC (23\%), than in the UN as a whole $(20 \%)^{67}$.

I will in the following chapter mention the most important regional documents from the Islamic world, and try to comment on how they measure up to the minimum standards that are set by the international community on the protection of individual human rights. The two latter documents, The Cairo Declaration on Human Rights in Islam and The Arab Charter of Human Rights ${ }^{68}$, are documents worked out by organizations on a governmental level. They are therefore important measurements on a general standpoint of the governments of the countries in the Islamic parts of the world. Before those two I will include The Universal Islamic Declaration of Human Rights ${ }^{69}$, a product of a non-governmental organization - the

\footnotetext{
${ }^{66}$ Algeria, Bahrain, Djibouti, Egypt, Iraq, Jordan, Kuwait, Lebanon, Libya, Mauritania, Morocco, Oman, Palestine, Qatar, Saudi Arabia, Somalia, Sudan, Syria, Tunisia, United Arab Emirates and Yemen.

${ }^{67}$ Information about what states have ratified which covenants and treaties can be found on the webpage of the UN High Commissioner for Human Rights, www.unhchr.ch/pdf/report.pdf

${ }^{68}$ Both documents can be found at the University of Minnesota, Human Rights Library, wwwl.umn.edu/humanrts/instree/auoz.html

${ }^{69}$ University of Minnesota HR Library ; www1.umn.edu/humanrts/links/islam.html
} 
Islamic Council. Since they are known to represent the interest of conservative Muslim, and since the document often is referred to in the debate on human rights, I've chosen to include also that human rights scheme in the analyze. Before I begin to analyze these three documents, which are drafted to constitute alternatives to the UN documents on human rights, and in one way or another are adjusted to fit Western norms, I will describe a document, not produced by any government or organization. As an example of Islamic doctrine it is simply the theories on the subject of Islam and Human Rights by one man; Abu al-'A'la Mawdudi. Mawdudi. He was a prominent Pakistani Sunni religious leader and founder of the organization Jama'at-i-Islami, a group committed to reinstate Islamic law and establish an Islamic state in Pakistan. He has written several documents on the issues of Islam and contemporary problems, and has been widely translated ${ }^{70}$. Since there are few Islamic theorists who have put their thoughts into writing, I've found that many articles or web-pages connected to political Islam are quoting him, or expressing ideas very similar to his. I will therefore use Mawdudis's document "Human Rights in Islam",71, as an example of a strictly Islamic view of human rights in the doctrine.

\subsubsection{Human Rights in Islam - A. A. Mawdudi 1975}

\subsubsection{General human rights}

The Mawdudi document is based on a series of lectures he held in 1975, and is therefore evidently constructed in a different way than the following documents, which are drafted with the purpose of eventually becoming treaties or legal documents. It is divided into four chapters. The first one is generally about the Western and Islamic approach to human rights. Chapter two is about basic human rights, and chapter three about the, according to the author, more extended human rights in the Islamic state. The fourth chapter is devoted to rights of the enemies at war, which I will exclude since it treats a whole different set of rules in International law than those of the UDHR and the Covenants.

The document begins with a rather harsh criticism of the Western illusion that all good must come from Western sources and ideas. The Western monopoly on human rights is argued against with the notion that no Western concept of human rights existed before the $17^{\text {th }}$ century. The first practical proof or demonstration of these rights didn't come until the $18^{\text {th }}$ century, through the proclamations and constitutions of America and France. In Islam there

\footnotetext{
${ }^{70}$ Tergel, p 90-91

${ }^{71}$ www1.umn.edu/humanrts/links/islam.html
} 
have on the other hand existed human rights since the birth of the religion. Since these rights are sanctioned by God, the rights stated in proclamations and resolutions by the UN can't even be compared to them. Rights given by men can also be withdrawn by men. They are rather philosophical concepts, which have no sanctions behind them. This is where complications for human rights advocates often arise. Since the concept of universal human rights is based on the idea of natural rights given to man on virtue of being human and not through any divine revelation, they may be hard to justify when opposed to a culture where all right and duties are formulated by God. It is often hard to take the discussion further than that in an attempt to compromise with an Islamic fundamentalist, since they don't consider themselves to be in the position to alter the perfected rules of God.

So what Human Rights are according to Mawdudi contained in the Islamic law?

In the so-called basic rights, which include all humans not just those in an Islamic state, eight different rights are enumerated. I will in the presentation of these articles use the titles Mawdudi uses, since they show how his concept of what constitutes a right is not always coherent with what we would define as such:

\section{The right to life}

This, the most basic of all rights and also one of the opening articles in the UDHR, does not constitute a problem in Islamic law. It is based on verse 5:32 "Whosoever kills a human being without any reason like manslaughter, or corruption on earth, it is as though he had killed all mankind.."72 There is however an exception to the rule in verse $6: 151$, where it is said that killing a person through the due process of law is permitted. The law referred to obviously is the Sharía, which would make it possible to sentence people to death according to its rules about apostasy. The ICCPR does on the other hand in article 6 allow countries who haven't abolished death penalty, to impose it for the most serious crimes. The US can of course be used as an example of a Western country that still hasn't abolished death penalty. The article does not define what constitutes "the most serious crime", except that it has to be "in accordance with the law at the time of the commission of the crime". In theory there is consequently no obstacle for an Islamic state, where a legal system based on Sharía is in force, to have death penalty on what according to that law is considered the most serious crime. Article 6 does however also include rules about appeal and chance of pardon. This might not be complied by an Islamic court, but if the death penalty is allowed in the first place

\footnotetext{
${ }^{72}$ I will in my references to the Qur'an use the translation by Abdullah Yusuf Ali, Quatar National Printing Press, 1946
} 
one can consider whether the details around it aren't partly just rhetorical. Mawdudi does not stop with just establishing that the right to life for all humans is included in Islamic law, but claims that Islam is alone in granting this right to everybody. The Western declarations and constitutions pretending to do so, in reality are applicable to either only their own citizens or the white race alone. According to Mawdudi, the violations of rights of the aborigines and the Indians in America are examples of this. These kind of anti-western statements are unfortunately not unusual in Islamic documents, although probably triggered by the similar prejudice often shown against the Islamic-Arabic culture.

\section{The right to the safety of life}

It is according to Mawdudi a duty for all Muslims to save another human being, if his life is in danger and if it is within their power to save him. The thought exists in many countries national legislation, although maybe not in the Islamic meaning of feeding a starving man. As it imposes duties on individuals rather than on the state, it however doesn't exist in any of the UN conventions and a comparison with universal human rights is not possible.

\section{Respect for the chastity of women}

The right to chastity of women is not either a human right as understood in international law. The rights of women are as mentioned before one of the most complicated fields in Islamic law versus international human rights law. According to Mawdudi the right of respect of the chastity of women seems to be defined as the right of women not to be raped or in other ways assaulted. He refers to this right as only existing in Islam, since Western armies in all times have raped and abused the women of the countries they conquered. According to him this never existed after a conquest of a Muslim army. Whether this is true is questionable ${ }^{73}$. This is however not relevant for the theoretical argument. Violations of human rights in practice often have little to do with whether they in theory are permissible, and the crimes against women in wartime are hardly allowed under any legal or moral system. The respect of the chastity of women can however, on the contrary of actually being a right of women, constitute a restriction of the woman's personal freedom. The Talibans for example argued that the reason to keep women secluded and enshrouded, is to make sure that her chastity is not at risk. The rights of women are not further discussed in Mawdudi's human rights document. This is probably not a coincidence since he in many other writings has made it clear that in his

\footnotetext{
${ }^{73}$ Mayer, p103-104
} 
opinion equality of women, such as in secularized societies, only leads to promiscuity and the undermining of the family. ${ }^{74}$ To think that all the rights in the documents apply equally to women, in lack of evidence of the opposite, would consequently be too optimistic. Not mentioning women's rights is rather a sign of the unwillingness to discuss the subject.

\section{The right to a basic standard of life}

Based on the verse "..and in their wealth there is acknowledge right for the needy and destitute." (51:19 Qur'an), this right is the duty of Muslims to economically help those less fortunate than themselves. This idea can be found in most religions, Christianity included, but does not have a counterpart in the UDHR or the covenants, as it puts the duty on the individuals rather than the state to attend to the satisfaction of everybody's basic needs. The right to some kind of social security and a minimum economic level can however be found both in the UDHR and the ICESCR, but then with the state as duty-bearer.

\section{Individual's right to freedom}

Defined by Mawdudi as the right not to be enslaved, this right to the individual's freedom is equal to article 4 in the UDHR stating that "No one shall be held in slavery or servitude; slavery and the slave trade shall be prohibited in all their forms." After declaring slavery as condemned already by the Prophet himself, Mawdudi starts a long exposition of the Muslims superiority over the West in abolishing slavery. I have often found a similar discussions about who abolished slavery first and when both in Islamic and Western literature, as if it was some kind of competition. Since slavery undoubtedly is one of the lowest points in our history of human rights, but now is theoretically prohibited in all countries both Western and Muslim, I however find this discussion lacking interest from any other than an historical perspective. In the debate of human rights today, slavery is not an issue where any differences of opinion exist.

\section{Right to justice}

The right to justice is defined the UDHR and ICCPR as for example the right to a fair trial, the right to recognition before the law and the right to protection of the law. Mawdudi's article does not mention any of these rights. The right to justice article in his document only states that according to the Qur'an, no Muslim can ever be unjust to anyone, non-

\footnotetext{
${ }^{74}$ Mayer, p 104
} 
discriminatory of if they are citizens of their other countries or people of their tribe, race or the Muslim community as a whole. This "justice of Islam", which consequently is extended to all human beings is however not further defined, and it is therefore difficult to conclude whether it is in coherence with the standards of international law or not.

\section{Equality of human beings.}

Discrimination against women and non-Muslim is as mentioned earlier a field where it due to rules in the Sharía is hard for the Muslim societies to comply with the Western norms of equal rights. By including the right of equality, Mawdudi does however not attempt to clarify that area, and the title is somewhat misleading. At various times in the article he states that no discrimination based on color, race, language or nationality is allowed in Islam, and that God has given man his right of equality as a birthright. Equality based on religion or sex is never mentioned. Mayer, in her book "Islam and human rights: Tradition and Politics “ 75 considers this statement to be empty, as if the US would outlaw discrimination based on caste while ignoring to regulate discrimination based on race, which is an actual problem area, or if a Hindu environment would do vice versa. Not dealing with the rights of women and religious minorities in an Islamic document on human rights is consequently only a hypocritical way of allowing these discriminations to continue.

\section{The right to cooperate and not cooperate}

Based on the general principle in Islam; "Co-operate with one another for virtue and heedfulness and do not co-operate with one another for the purpose of vice and aggression" (5:2 Qur'an), this is the right for Muslims to support any activity seen as noble and righteous. Even if the person who undertakes the deed isn't himself a Muslim, the duty to help him exists for the pious Muslim. If on the contrary somebody perpetrates deeds of vice and aggression, he will not be entitled to support even if he is a Muslim. This right or duty or whatever it is to be considered as does not have any counterpart in international law and can therefore hardly be subject to comparison.

\footnotetext{
${ }^{75}$ Ann Elisabeth Mayer is an associate professor of legal studies at the Wharton School of the University of Pennsylvania. Her book "Islam and human rights: Tradition and politics", Westview Press, Oxford $3^{\text {rd }}$ ed. 1999 , is one of the most acclaimed and well-known studies in the field of Islam and human rights. Both sides in the debate on whether human rights and Islamic law are compatible tend to quote her or comment on her opinions, which make her book a good start for further reading for the interested.
} 


\subsubsection{The rights of citizens in an Islamic state}

The third chapter of Mawdudi's document contains the more extended rights of the members of an Islamic state. This limitation at once constitutes a problem, since human rights in international law are universal and therefore in no situation can be altered to just apply to a certain group, such as citizens of a state. I do however not think that the purpose of Mawdudi was to establish that Muslims have rights that other people haven't. The rights in the second chapter, described above as general human rights, are due to all human beings since they are rights and duties imposed on individuals in their behavior amongst each other. The rights that Mawdudi introduces in the third chapter are rights that the individual holds against the state. The definition of them as rights of the citizens of an Islamic state, is simply made because the rules imposed by the Qur'an with the state as a duty-bearer only can be actualized in an Islamic state. The rights and duties imposed on individuals in chapter two are to be obeyed by all Muslims, even if resident in a non-Islamic state. In the description of almost all rights it is stated that the dhimmis (non-Muslim minorities, at least the people of the book) are entitled to the same rights as the Muslims if they are citizens of an Islamic state.

The chapter includes fifteen "articles", or rather expositions on different rights. Most of them are somehow related to either the field of freedom of conscience and expression etc., or to the field of rights connected to the legal system, such as the right to a fair trial and equality before the law. The chapter starts out with the right to security of life and property, which was established as the first right also in the chapter of general human rights. In this development of the former discussion, Mawdudi clarifies that the general rule that killing another human being generally is wrong, but may be allowed due process of law and only after a ruling by a legitimate court of law. It is consequently never allowed for a Muslim to kill somebody who breaks the rules of the Sharía on his own initiative. The "honor" murders of women guilty of adultery by family members are thus only a cruel tradition. The article is also extended to include the right of security of property. The general right to the basic necessities of life is also repeated in the second chapter, with the difference that the right is held against the state and not other individuals.

The rights related to freedom of conscience and expression are complicated by the fact that in any document based on a conservative interpretation of the Sharía, problems will arise in the field of blasphemy and apostasy. The two articles establishing "Freedom of conscience and conviction" and "Protection of religious sentiments" does on one hand emphasize that Islam 
neither would force anyone to convert to Islam, nor allow any harassment of the "people of the book". It quotes verse 29:46 from the Qur'an; "Do not argue with the people of the Book unless it is in the politest manner". On the other hand there is inevitably going to be a limitation in these freedoms when it comes to Muslims wanting to convert to another religion. This aspect is however not mentioned in the document, which would indicate that in similarity with the rights of women Mawdudi doesn't seem to acknowledge this as a problem, or intend to extend the right of freedom to religion to include conversion from Islam too. In the article discussing freedom of expression, the limitations of Islamic rules compared to rules on the same subject in international law is easier to trace. The right to freedom of thought and expression is conditioned with that it should not be used for "spreading evil and wickedness". According to Mawdudi this makes the concept of freedom of expression superior to its western parallel, since it protects the citizens of the Islamic State of being subjected to "abusive or offensive language in the name of criticism". This is however confusing the concepts somewhat. Freedom of expression is also in the ICCPR restricted if provided by law to respect the rights and reputations of others, and also to protect ordre public among other things. I do however not think that what is aimed at in Mawdudi's article is a limitation of the right to protect individuals from being personally offended or defamed, since he establishes this "right" in a separate article named "The protection of honor". The aim is rather to open up to the limitations of freedom of expression that the rules of blasphemy and apostasy in the Sharía bring about. Statements later in the article, such as the obligation of all true Muslims to forbid people to adopt the paths of evil, also indicates that speaking ill of the prophet or criticizing Islam would not be accepted under the freedom of expression in an Islamic state, even though there is no concrete definition of "evil or wickedness" in any of the articles. This assumption can however be made since both Mawdudi and his organization are known to have a rather fundamentalist view of Islam, even supporting death penalty for conversion from Islam. ${ }^{76}$ The article on freedom of association includes similar limitations. It conditions the right to form parties and organizations with that it can't be for the purpose of spreading evil and mischief. The corresponding right in the ICCPR also includes the possibility to limit this right. These limitations can be imposed by law, if it is in the interest of national security, public safety, ordre public, protection of public health or morals or the protection of rights and freedoms of others. One can of course play with the thought that also these somewhat vague definitions, especially "public morals", can be interpreted rather extensively. This could leave

\footnotetext{
${ }^{76}$ Mayer, p 16
} 
plenty of room for limitation in the freedom of association (and also freedom of expression) to criteria we in the Western world consider disturbing for morals, but maybe in other cultures would seem unmotivated.

The rest of the articles are in some way related to the legal or judicial system. As mentioned earlier most countries in the Islamic world have both secular and religious courts. The religious courts are regulating mainly family-matters, such as divorces and heritage. One of the subjects discussed by Mawdudi is "Equality before the law". He rightly points out that Islam doesn't discriminate on base of class, and therefore all men are equal before the law as they are equal in all other aspects of society. He also emphasizes that dhimmis have the same rights as Muslims. This might be true, but when it comes to the religious courts, especially in the countries as Iran where no secular courts exists, non-Muslims also have to live after rules that are set by a religion the don't even adhere to. Even if the laws may be applied to them equally, the thought of having your daily life totally governed by a God you may not even believe in, might be disturbing in many situations. One concrete example to illustrate this is the situation of the non-Muslim women in Iran. They are forced to obey the hijab-rules, enforcing major restrictions in how they are allowed to dress, despite the fact that for them there obviously isn't any religious motivation or believed "divine" reward for doing so.

The remaining articles are more or less compatible with international law, like the right to security of personal freedom and the security of private life. Some articles are without a counterpart in international rules but not opposed to them, and will be left outside the discussion. It is however interesting to note that the last article in Mawdudi's chapter three on the rights of the citizens in an Islamic state is "The right to participate in the affairs of the state". In this article Mawdudi establish that the Qur'an gives the Muslims in an Islamic state the right to elect their government and representatives through free and independent elections. Whether democracy is compatible with Islam or not is an issue often debated, especially since many of the states considered Islamic does not have a democratic rule. Still, Mawdudi's document is actually the only one of the Islamic human rights documents referred to here that mentions the right to representative democracy.

Mawdudi's document has obvious shortcomings in reaching up to the standards of international human rights, such as set in the UN documents. Unlike the next three documents I will describe, one must however remember that this document is not an official one. The 
purpose is not trying to compromise with international law or establish an alternative set of rights based in the idea of cultural relativity. It is simply a conservative Muslim's description of what rights are included in the Qur'an and Sharía. The document can however be seen as authoritative doctrine, and are relevant as a guideline for many Muslims. The document avoids many sensitive questions, and the fields in which the Sharía is hard to adjust to international law are often carefully avoided.

\subsubsection{The Universal Islamic Declaration of Human Rights (UIDHR) ${ }^{77}$}

The UIDHR was promulgated in 1981 at the UNESCO headquarters in Paris. The document was prepared by representatives from Pakistan, Egypt, Saudi-Arabia, and other countries in the Islamic Council, a London based organization affiliated with the Muslim World League, an international NGO with its headquarters in Saudi-Arabia. According to some, it has, as mentioned earlier, a tendency to represent the interests of conservative Muslims. ${ }^{78}$ The declaration exists in two versions, one in English and one in Arabic, and there is a significant difference between the two versions ${ }^{79}$. According to Mayer, the English version, at least at a first brief viewing, appears to be more in compliance with the UDHR, while the one in Arabic is relying much more on Sharía to justify rights. But also in the English version one can read in the explanatory notes:

\footnotetext{
" In the exercise and enjoyment of the rights referred to above every person should be subject only to such limitations as are enjoined by the Law for the purpose securing the due recognition of, and respect for, the rights and freedom of others and of meeting the just requirements of morality, public order and general welfare of the Community (Ummah)"
}

It is also stated in the explanatory notes that by the Law, the text refers to the Sharía - defined as the totality of ordinances derived from the Qur'an and Sunna, and any other laws that are deduced from these two sources by methods considered valid in Islamic jurisprudence. This is of course from our point of view strongly limiting the human rights such as they are described in the UDHR. Since the standards of what is defined as Sharía are left relatively open, it

\footnotetext{
${ }^{77}$ Tabet Koraytem calls this same declaration The Islamic Universal Declaration of Human Rights (IUDHR), so I'm not sure about the correct term. I will however continuously use Mayer's.

${ }^{78}$ Mayer, p21

${ }^{79}$ Mayer p21 and Tabet Koraytem, Arab Islamic Development on Human Rights, Arab Law Quarterly 2001, p260
} 
leaves the possibility for different interpretations and applications. Consequently it is almost impossible to predict what restrictions might occur.

A clearly theocratic approach is taken already in the foreword of the declaration, where it is stated that all human rights are given by God, and God only since he is omnipotent. Since these rules are divine they are sufficient in protecting the community, and no ruler or government can violate or change them. Accordingly, all the articles in the declaration have an explicit reference to certain verses of the Qur'an or specific parts of the Hadith. Another difference from most Western human rights documents is the existence of a corresponding duty to many of the rights in the declaration. For example in article XII, it is stated to be the "right and duty of every Muslim to protest and strive (within the limits set out by the Law) against oppression..” . Article IV, one of the paragraphs on Right to Justice, in a similar way contains the duties to defend rights of other persons and the community, protest against injustice and refuse to obey any command which is contrary to the Law. This is a divergence from the UDHR and other international declarations on human rights, which focuses almost only on rights and rarely mentions corresponding duties. There are further rights included in the UIDHR that are not directed against the state, but has another individual as opponent, indirectly creating a duty for that individual. Examples of this are the rules in articles XIX and $\mathrm{XX}$, regulating family matters and the rights of the married woman, which obliges the husband to maintain his wife and children, and entitles the wife to special respect, care and assistance from the family in times of motherhood. This might seem a bit odd from our Western view of human rights, since we only define human rights as rights we have in relation to the state or other authorities. In a document referring to the Islamic law this is however not that strange, regarding that that whole system is based on a worldview where the individual is part of a bigger community (the Ummah). To achieve the ideal community, the individuals have to fulfill certain duties against God and the Ummah, but they also have Godgiven rights.

The declaration remains, at least in the English version ${ }^{80}$, relatively neutral in "sensitive" questions such as women's rights, the rights of minorities and freedom of belief. None of these issues are openly confronted. But also in this version one can easily read between the lines that the protection of these rights is not sufficient, if compared to the standards set in the

\footnotetext{
${ }^{80}$ According to Mayer, p 106-113, the Arabic version is more clear in for example the field of women's rights. Since I'm lacking the ability to read the Arabic text I can only refer to the English version in analyzing the declaration.
} 
universal declarations. In article XII Right to Freedom of belief, Thought and Speech, paragraph a), the right for every person to "express his thoughts and beliefs as long as he remains within the limits prescribed by the Law", is established. Keeping in mind that the Law is defined as the Sharia, an obvious problem on how to deal with the Islamic rules on apostasy arises. At a minimum, a system based on the Sharia will probably prohibit trying to convert people to a different faith than Islam, and to speak disparagingly of the Prophet. This would be a restriction in the freedom of expression, incompatible with the international standards of human right.

The Sharía, according to orthodox interpretations, prohibits conversion from Islam. In many of the countries considered Islamic, it is also illegal or at least a problem when it comes to civil status ${ }^{81}$ to convert from Islam (obviously conversion from another religion to Islam is rather encouraged). This also applies to all forms of apostasy. If using these kinds of interpretations of Sharía, the freedom of religion is also strongly limited. There is however also an article (XIII), stating that "Every person has the right to freedom of conscience and worship in accordance with his religious beliefs." This article does not mention "the Law" in its wording, but in the references of the declaration it refers as all the other articles to a paragraph in the Qur'an. As I see it there is nothing in the Qur'an prohibiting the practice of other religions. Islam is even explicitly tolerant to the "people of the book" (ahl al-kitab), the Christians, Jews and Zoroastrians, who are allowed to freedom of worship and security of person and property, as long as they pay a poll tax (jizya). But in some aspects they hold the statues of second-class citizens in an Islamic state, and it is questionable whether it is to be seen as freedom of religion, as we define it. ${ }^{82}$ The non-Muslim minorities are dealt with in article X, according to which their rights are governed by the Qur'anic principle"There is no compulsion in religion”, based on the Qur'an 2:256. The traditional interpretation of this verse focuses on the right of the dhimmis (non-Muslims) not to be forced to convert to Islam, rather than on their right not to be discriminated against based on their religion. In the English version of the article, the term non-Muslims seems to be referring to all other religions, but in the Arabic version the term ahl al-kitab (people of the book) is used instead of non-Muslims.

\footnotetext{
${ }^{81}$ For example, according to Sharia, if one of the spouses in a marriage converts, which incurs civil death (meaning among other things that a person can't be legally married or inherit), the marriage is automatically dissolved. This happened to the Egyptian professor Nasr Hamid Abu Zaid, who in 1994-96 was accused of apostasy and got the marriage to his Muslim wife dissolved. The couple eventually had to seek asylum in Europe to be able to live together without the threat of getting killed. (Mayer p152)

${ }^{82}$ Dalacoura, p 46
} 
This leaves the statues of other religious minorities, who in pre-modern Sharia were considered non-persons, unregulated.

The protection of the rights related to freedom of religion and rights of minorities is obviously one of the more complicated questions to regulate in a human rights declaration based on a religious system of rules such as the Sharía. In the UIDHR, the protection in parts seem to be sufficient, but if interpreted according with the references to the Sharía it is uncertain whether it is possible to reach a level that would be considered equivalent to the UDHR.

In the UIDHR the rights of women aren't specifically treated, possibly avoided because of the ambivalence towards the subject. The position of the women still turns up in the articles XIX Right to Found a Family and Related Matters, and XX Rights of Married Women. The right to get married is an unqualified right in the UDHR, meaning that a person is free to marry anyone he or she finds suitable (art 16.1 "Men and women of full age, without any limitations due to race, nationality or religion, have the right to marry and found a family"). In the UIDHR, the corresponding article (XIX .a) has a slightly different wording: "Every person is entitled to marry, to found a family and to bring up children in conformity with his religion, traditions and cultures." The phrase "in conformity with his religion", supposedly read as according to Sharía, will on contrary to the international rule impose restrictions on the right to get married. The Sharía does for example prohibit women to marry non-Muslims, and men are only allowed to marry a woman who's either Muslim or member of the "people of the book". It is also prohibited, as mentioned earlier, to marry or stay married to an apostate. The article XIX a) further states that every spouse in a marriage is "entitled to such rights and privileges and carries such obligations that are stipulated by the Law”. With a very fundamentalist reading of the Qur'an, as for example that of the Talibans where the women's rights are strongly limited, the article does not prevent an unequal treatment of women, at least not within the marriage. The rights of the unmarried woman are not at all discussed in the declaration. But since all of the articles that appear to refer to all persons, have references to Sharía, and women in most interpretations of Islam has an inferior position to men, one might doubt that un-married women would have more extended rights than their married counterparts. Getting married is also normally considered the only acceptable path to choose for a respectable woman, and before marriage she is under the guardianship of her father, or another male relative. Interesting to note is also that one of the verses in the Qura'n referred to in connection with art XIX (and according to Mayer incorporated in the text in the Arabic version of the declaration), is verse $2: 228$. This verse is often, as mentioned earlier, used by 
conservatives to confirm that Islam mandates male superiority. Another fact revealing that the equality between men and women is not according to the standards of the international human rights documents, although there is nothing directly pointing this out in the UIDHR, is the mere existence of an article regulating the rights of married women. In a society where the rights of men and women are equal, whether they are married or not, there would not be a need for a special regulation of the status of the married woman. The married woman is according to the article entitle to for example living in the house in which her husband lives, and receiving means necessary for maintaining a standard of living not inferior to that of her spouse. These are of course not negative rights, since they protect women from being economically mistreated within the marriage. If women were not seen as inferior to start with, and the husband considered the only or at least main provider of the family, there would on the other hand not be a need for rules that protected her and not simply the spouse less well of financially. The references to article XX include the verse 4:34 of the Qur'an, which also is cited in the Arabic version ${ }^{83}$. It includes the obligation for the husband to provide for his wife, similar to the English version, but makes the connection that this is the reason why man are in control of woman. Other rights of the married woman mentioned in the article, are the right to obtain dissolution of marriage and to inherit from her husband and other relatives - both in accordance with the Law. Divorce is however harder for women to obtain than it is for men. Due to Sharía it is almost impossible without the consent of the husband, and the rules on heritage in Sharía allows women only half the share of a male. Furthermore a widow can inherit, as a maximum, a quarter of her husband estate if there are no children, and oneeighths if there are (Qura'n 4:12). If the husband has more than one wife, since the Qur'an allows up to four wives, the share consequently gets even smaller. These rights are consequently rather restrictions than extended rights. When it comes to the rights of women, the conclusion will have to be that, even if the subject a first glance might seem to be carefully avoided in the UIDHR, the situation of women is supposed to be regulated mainly according to principles in the Sharía. As pointed out earlier this leads to a very unpredictable application of the law, dependent on what interpretation of the Sharía the Islamic state that potentially ratifies the declaration chooses. Our western standards of equality between the genders will however be difficult to reach up to, even with a less conservative school of interpretation, since the idea that men and women have different roles in society has such a firm base both in tradition and in the Islamic religion. One article that further is worth

\footnotetext{
${ }^{83}$ Mayer, p 111
} 
mentioning is article XIX e), according to which no person may be forced into a marriage or loose or suffer diminution of legal personality on account of marriage. This is one of the few articles that might be seen as an exception to the rule that all articles are strictly Sharía based. The Maliki School, for example, allowed a girl's guardian to marry her of without her consent. Marriages without the consent of the woman is still an existing problem in many Muslim societies, although it is outlawed in most Middle East countries. It is therefore promising to see this issue addressed in a declaration produced by an organization considered conservative.

The UIDHR is a good example of a human rights declaration based on a theocentric foundation of values. Already in the preamble it is made very clear that the declaration and the rights in it have a religious focus, and although it does make an effort to measure up to the international standards, it will not work in the same manner as a secular human rights document. This would on the other hand probably apply to most human rights documents with a religious base. Few religions are as focused on individual rights as the enlightenment philosophies inspiring the western human rights ideas are.

\subsubsection{The Cairo Declaration on Human Rights in Islam 1990}

The Cairo Declaration on Human Rights in Islam, in both an English and an Arabic version, were submitted to the UN by the Organization of the Islamic Conference (OIC) prior to the World Conference on Human rights in Vienna in $1993^{84}$. The central preoccupation of the conference itself was the matter of whether human rights are linked to Western culture and values, or if they should and could be universal. Strong voices where raised for more consideration of cultural differences - cultural relativism, especially from non-western countries. At one point Iran, Saudi-Arabia and Iraq joined together in pressing the UN Commission on Human Rights to accept the Cairo Declaration as an alternative for the Muslim countries. The existing human rights system is according to them excessively Western and leaves no room for other cultural and religious values. This view was however rejected by the UN Secretary General Kofi Annan, who insisted on the universality of human rights $^{85}$. The Cairo declaration is important for two reasons, even though the UN hasn't accepted it. It is one of the more recent documents of its kind, but it clearly continues the

\footnotetext{
${ }^{84}$ Mayer, p 23

${ }^{85}$ Ibid
} 
trend earlier established in previous Islamic human right schemes. It was also endorsed by the foreign ministers of the OIC in August 1990. The OIC consists of all countries considering themselves Islamic and the document can therefore be seen as some form of political consensus on human rights from the perspective of the Muslims states, even though they don't exactly have a common stand on the application of Sharía.

Since this declaration is more of an official governmental document, compared to the conservative UIDHR, it tones down the references to Sharía. There is however no doubt that also the Cairo declaration has a religious foundation. The declaration is a mix of political and socioeconomic rights, and similar to the UIDHR it includes rights that have corresponding duties addressed to other individuals and not the state. It begins with a preamble recognizing the importance of having an Islamic human rights document that will serve as a general guidance on human rights matters in the Islamic states. It also inclines that all rights are of divine source and establishes that:

\footnotetext{
"..fundamental rights and freedoms according to Islam are an integral part of the Islamic religion and that no one shall have the right as a matter of principle to abolish them either in the whole or in part or to violate or ignore them in as much as they are binding divine commands, which are contained in the Revealed Books of Allah and which are sent through the last of His Prophets to complete the preceding divine messages.."
}

When it comes to the groups that traditionally have a weaker position in an Islamic state, such as women and non-Muslims, their position is not openly confronted in this declaration either. Article 1 a) talks about all men being equal in terms of basic human "..dignity, and basic obligations and responsibilities, without any discrimination on the basis of race, color, language, belief, sex, religion, political affiliation, social status or other considerations". It does however not mention that there would be rights that are equal to all individuals. One might think that this is only a rhetorical difference, but it does leave room for interpretations where equal dignity for example between men and women doesn't necessarily lead to the same set of basic rights. The article does neither constitute a sufficient protection of freedom of religion. It prohibits discrimination on basis of religion, at least as far as "dignity" is concerned, but it refers to the "true religion"( Islam), as the guarantee to enhancing it. This might lead back to the apostasy rules of the Sharía. In 1 b) it is also made clear that all human beings are Allah's subjects, and no one has superiority over another "except on the basis of 
piety". The wording is somewhat vague, but it seems like the article wouldn't be enough to protect for example a person accused of apostasy. There are two more articles concerning religion, article 18, establishing a right for the individual to live in security "for himself, his religion, his dependents, his honor and his property", and article 10 that prohibits pressuring people to convert from Islam, or to atheism. Article 10 is clearly a restriction in the freedom of religion and not a right. Article 18 does however suggest a certain standard of protection of religious minorities and freedom of religion. But reading for example article $23 \mathrm{~b}$ ), in which the right to assume office is regulated according to Sharía (which means excluding the possibility for non-Muslims to assume public office) it once again appear to be an empty statement. It might be religious tolerance, allowing everybody to practice their own religion, rather than religious freedom, where a persons religion would not lead to any restriction of his other rights.

Many rights in the UDHR are unqualified, like the right to life and security (art 3), and the right not to be subject to torture or cruel, inhuman or degrading treatment or punishment (art 4). In the Cairo declaration these rights exist, but with the difference that they can be put aside for reasons prescribed in the Sharía. (Art 2a and 2d). This leaves room for the pre-modern Sharía rules on the so called Húdud-crimes, the crimes against which God himself has set limits, and for which the punishment is directly formulated in the Qur'an. This includes for example the physical punishments for theft and adultery, often discussed in western media as inhuman and uncivilized. Theft is in verse 5:36(41) punished by cutting of the hands of the thief. The following verse does however make an exception for the criminal who repents his crime. Adultery is punished by death for women, if the betrayed husband can find four witnesses whom actually seen the act of adultery (4:15-16). There is also another verse regulating adultery (24:2), where flogging is the punishment men and women equally. This rule does not call for witnesses. The húdud punishments are a controversy also in Islamic states, and many reformist consider them a remnant from an Islam not adjusted to modern society. Fundamentalists often consider them laws given by God and therefore not a matter of compromise. Whatever one thinks about the existence of crimes sanctioned by God, there is however no doubt that if physical penalties such as flogging, cutting of hands or death penalties are carried out in the name of Sharía, it is not compatible with the UDHR's articles 3 and 4. 
The rights of women are vaguely discussed in article 6 . Women are said to be equal to man in “..human dignity, and has her own rights to enjoy as well as duties to perform", but no definition is made about what these rights and duties are. Since the article makes no reference to Sharía, the interpretation of it is even harder. The formulation that women are equal to men in dignity, but has her own in rights, does however give an indication that all other rights in the declaration does not automatically apply to women too. The duty of the husband to provide for the family is also established in this article. This further indicates a conservative way of seeing the man as the provider, and his superiority over the woman is thereby probably presumed. There are also other relevant articles, such as freedom of movement and right to public office, which refer to rules in the Sharía. With a conservative interpretation this would lead to restrictions for women. Due to some traditions, women are not allowed to travel without the company of a male relative. The right to marry, in art 5, is restricted in a similar way as the corresponding article in the UIDHR. It establishes that the right to marry shall have no restrictions stemming from race, color or nationality. It leaves out religion, consequently leaving room for an application of the Sharía rules prohibiting women to marry a non-Muslim, and the other restrictions mentioned earlier.

One interesting article dealing with equality is art 13, which states the right to fair wages for work, "without any discrimination between males and females". According to Mayer, the somewhat vague formulations in the same article; "everyone shall be free to chose the work that suits him best and serves his interest as well as those of the society" and "he may not be assigned work beyond his capacity", might on the other hand lead to women being excluded from certain fields of work. ${ }^{86}$

Article 22 deals with freedom of expression. The freedom of expression can hardly be interpreted as anything else but strongly restricted due to this article. Everyone has the right to express his or her opinion freely, as long as it isn't contrary to the Sharía. This brings us back to the problem with apostasy. In art $22 \mathrm{c}$ ) there is another, maybe even wider restriction to freedom of expression and freedom of the press. It establishes that information is a vital necessity to society, but then names a variety of restrictions to this such as information violating the sanctities or the dignity of the Prophet, undermining moral and ethical values and disintegrate, corrupt or harm society or weakens its faith. In an Islamic state those would be pretty strong restrictions for example for non-Muslim media. The freedom of expression is however not unrestricted in the ICCPR either. It can be subject to certain restrictions if it is

\footnotetext{
${ }^{86}$ Mayer, $\mathrm{p} 121$
} 
provided by law, and necessary for the respect of the rights and reputations of others and the protection of national security or of public order, or of public health or morals (art 19). To be fair I guess one can say that at least the "public morals"-exception is as arbitrary as the ones in $22 \mathrm{c}$ of the Cairo declaration.

The last two articles of the declaration make one last connection between the declaration and the Sharía. They stipulate that all rights in the declaration are subject to the Islamic Sharía and that the Sharia is the only source of reference for the explanation or clarification of any of the articles. The consequence of this is that the Cairo declaration, even without any exact references to the Qur'an and Hadith as those of the UIDHR, has the same problem with predictability as the former document. The possibility that different schools of interpretation of the Sharía can be used to set the limits of the rights stated in the articles, leaves a wide spectrum of possible applications, of which the most extreme without a doubt falls outside the international human rights standard. Although I have not mentioned the articles in conformity with the international human right rules, but only high-lighted the fields in which the declaration does not measure up to international standards, it seems clear that the Cairo Declaration in resemblance with the UIDHR does not reach up to the western idea of universal human rights.

\subsubsection{Arab Charter of Human Rights 1994}

The Arab Charter of Human Rights is a document produced by the Arab League. The Arab League was founded in 1945, but before1968 non-of the members showed any interest in human rights, and the charter was not adopted until $1994^{87}$. The first draft was however prepared already in 1970, by a committee of experts established by the permanent Arab Commission. Due to lack of interest from many of the member states, and many reservations from those who cared to answer to the draft, it was discarded. In 1979 the idea was rejuvenated at a seminar convened by the Union of Jurists in Baghdad, where a new draft was produced. The draft was considered by the Council of the League, which decided in March 1983 to refer it to the member states for their view. After that the matter was postponed again, pending the adoption of the Cairo Declaration of Human Rights. The latter was adopted by

\footnotetext{
${ }^{87}$ An-Na'im Abdullahi A, Human Rights in the Arab World: A Regional Perspective, Human Rights Quarterly 232001, p 712
} 
the Islamic Ministerial Conference in Cairo in 1990. The Council of the Arab League adopted the Arab Human Rights Charter by Resolution 5437 of 15 September 1994. The Charter has not been ratified by any of the Arab states since the adoption of the League ${ }^{88}$. The Arab Charter on Human Rights is very different from the former two mentioned declarations (the UIDHR and The Cairo Declaration). The most obvious difference is that no reference to the Sharía is made in any of the articles. It is stated in the preamble that the eternal principles of brotherhood and equality among all human beings are established in the Islamic Sharía and the other divinely revealed religions, but apart from that Sharía is not at all mentioned. The preamble also reaffirms the principles of the UN Charter, The UDHR, the ICCPR and the ICESCR. This kind of reference to international documents can not be found in any of the other Islamic human rights documents. The Arab Charter does however also reaffirm the principles of the Cairo Declaration, which as I concluded earlier aren't always in agreement with those of the UN documents. The Arab Charter also stands out from the earlier mentioned documents in the way its articles are formulated. Most of the articles are cited, or at least close to the wording of a corresponding article in the UDHR, the ICCPR or the ICESCR. The initial article in the UDHR, establishing that all human beings are born free and equal in dignity and rights, and that they are endowed with reason and conscience, is however not to be found in the Arab Charter. Instead it starts out with an article declaring the selfdetermination of peoples and condemning racism, Zionism, occupation and foreign domination (the self-determination part is close in the wording of the initial article of the UCCPR). As I see it, this discrepancy from the UDHR has both historical and political reasons. The reason and rationality of man is an idea of the Enlightenment, and as mentioned earlier and this is hard to combine with a non-secularized world-view, where all rights are given by an almighty God. The statement condemning occupation, Zionism and so on are obviously a consequence of the Israeli-Palestine conflict, and the incomprehensible way the situation is handled by the Western states, and mainly the US. The fear in the Middle-East of what they call a re-colonization is also strong among certain groups, and although the Arab Charter is drawn up years before the US lead wars in Afghanistan and Iraq, beginning the declaration with this article might not be unmotivated.

Article 3 prohibits denial of fundamental rights of the member states, by virtue of international treaties and customs. Article 4 does on the other hand leave room for restrictions

\footnotetext{
${ }^{88}$ An-Naim, p 713
} 
to rights under the Charter if imposed by law and deemed necessary to protect "..national security and economy, public order, health or morals or the rights and freedoms of others." According to An-Naim, this is a vague exception opens the door for legislation that can undermine the rights of the Charter. ${ }^{89}$ This is true; however there is an almost identical exception in the UDHR art 29. The only difference between the articles is that the one in the UDHR adds that these exceptions only can be made in a democratic society. Exceptions made on the basis of the Sharía, if that is the official law of a country, stating for example different rights for women and motivating this with the necessity of keeping the moral standard concerning family unchanged, would be possible according to both of the declarations. The UDHR would however only permit the exception in the case a democratic government had made the law. This is not a too unlikely course of events. The movements of politic Islam are growing much stronger in the Middle East, especially now in times when the segregation between East and West is increasing. The possibility of a democratically elected Islamic government is no longer far-fetched (in Turkey there has for example already been Islamists in the government, although they after a coup had to leave it).

Although most of the remaining articles are more or less in compliance with the rules in the UDHR or the two covenants, apart from minor differences in formulation, there are still a possible discrepancy in the rules concerning freedom of religion and freedom of opinion. The freedom of belief, thought and opinion is stated in article 26 and the freedom of religion in article 27 . Article 27 contains a paragraph putting a possibly extensive exception to these freedoms, establishing that: "..No restriction shall be imposed on the exercise of freedom of belief, thought and opinion except as provided by law" It is consequently possible for a state with Sharía based laws, to keep rules prohibiting apostasy. Since the exception does not require the protection of another interest, such as moral or public security, it makes it easy to restrict any of these freedoms for a government, irrespective of whether it is democratic or not. The rules on apostasy make it, among other things, impossible for a Muslim to convert to another religion. This constitutes a breach of the article 18 of the UDHR, in which the right of everyone to change religion or belief is clearly stated. The right to marry, which as we've seen earlier often constitutes a problem in Islamic human rights schemes since the right to marry does not include marrying a person of any religion, is for some reason not regulated in the Arab Charter. Unlike the UIDHR and the

\footnotetext{
${ }^{89} \mathrm{Ibid}, \mathrm{p} 715$
} 
Cairo Declaration, the Arab Charter contains no article specifically regulating the rights of women. Article 2 clearly states that all individuals have the same rights without distinction to sex. The rights of women are never mentioned as a different set of rights. ${ }^{90}$ The Arab Charter seems to be the only of the Islamic documents where women's rights, at least in theory, are equal to those of men.

Religious minorities, which as mentioned earlier aren't always treated equal according to Islamic rules, have an article expressly protecting their rights. But article 37 only protects the right for minorities to not be deprived of their right to enjoy their culture or to follow the teachings of their religion. The corresponding article in the ICCPR is similar in its wording, but the expression "profess and practice their own religion" (ICCPR art 27) is however slightly more extensive than to "follow the teachings of their religion" (art 37). There is, as I see it, nothing in the Charter preventing the application of the Sharia rules regarding the special poll tax for religious minorities. The articles regulating who is allowed to seek public office, a right that in the former two mentioned documents could be limited by rules in the Sharía, is unlimited in article 33 of the Arab Charter. This is an improvement of the rights of the religious minorities. An-Naim claims in his article "Human Rights in the Arab World - A Regional Perspective", that the Charter fails to provide for the right to political organization and participation. His point might be right, as he refers to the earlier mentioned possibilities to restrict any of the rights in the Charter (art 4). There is on the other an almost identical right to freedom of peaceful assembly and association in article 28, as that of the UDHR, which as I see it demonstrates a will to acknowledge this as a right of importance. The right to form trade unions and to strike are also mentioned, which is a step in the right direction in many Arab countries where striking never has been a right provided by law. A deficiency that I find more disturbing in the Arab Charter, as far as political organization goes, is that no article or part of the preamble indicates that the political system of the State parties of the Charter should be democratic and based on the will of the people. In the UDHR, for example article 21:3 establishes the right for everybody to elect their own government through periodic and genuine elections, with equal and universal suffrage. In the Arab Charter, the rights at many times measure up to international standards, but as far as democratic values goes that is carefully avoided in its articles. This is perhaps not surprising considering the number of Arab States that still are far from what we would consider democracies.

\footnotetext{
${ }^{90}$ Except that you can't inflict death penalty on a pregnant woman and that the state should provide for special care for mothers and children. Both of these are however taken from the International HR documents.
} 
The Arab Charter also has a system of implementation included in articles 40-41. It is however a weak system based on the foundation of a human rights committee with seven members elected by the members State Parties. The member states have a duty submit a report to the committee every third year. They should furthermore give answers to the questions asked by the Committee. The committee shall after that report their views and comments to the Permanent Commission of Human Rights of the Arab League. The idea of having any rules on implementation is an improvement in comparison to the other Islamic documents, but it is a rather weak system. In comparison with for example the African Charter, which often is criticized for having a system where the individuals possibility to raise a complaint is formulated in a rather imprecise way ${ }^{91}$, the Arab Charter leaves the question of any communication between other parties than states and the committees completely unregulated.

Compared to the UIDHR and the Cairo Declaration, the Arab Charter of Human Rights is far more adjusted to the international human rights standards of the UDHR and the two Covenants. No direct references are made to the Sharía. Nothing in the articles indicates that a theocratic value forms the moral foundation of the declaration. But the Charter still lacks some components that would make it a fully equal alternative to the UN documents. It is also worth mentioning again, that the Arab Charter has not yet been ratified by the states of the Arab League, and therefore it has no legal significance.

\section{Regional Human Rights development in practice}

\subsection{Limitation}

I will in this chapter try to give a more practical aspect of the human rights development in Islamic countries, by describing how the adaptation of international human rights documents have been handled by the governments and the existence of governmental human rights activities. I will also further describe the situation of the local human rights NGOs, and last briefly discuss whether there is any human rights discourse within the sphere of political Islam. To narrow things down a little, I have chosen to focus on the human rights

\footnotetext{
${ }^{91}$ International Human Rights in Context, edited Henry J. Steiner and Philip Alston, second edition 2000, Oxford Press, Oxford p 924 ( from Chidi Anselm Odinkalu, "The individual complaints procedure of the African Commission of Human and People's Rights: A preliminary Assessment" 1998
} 
development in the Arab countries. Studying all the countries in the Organization of the Islamic Conference (being all the countries that define themselves as Islamic countries in the world) would be far too extensive. Since it is difficult to find a general definition of which states are "Arab" states, I will in this chapter use this term meaning the member states of the Arab League ${ }^{92}$. The choice of the Arab countries as a criterion seems natural, since it was in that part of the world Islam first appeared and still today this is where you find the states with the highest percentage of Muslims. In these countries, religion has a very strong influence on politics. The member states of the Arab League are however very diverse, and the Charter of the Arab League does not define what is an "Arab state". The decision of who's allowed to join is simply made by the pre-existing members. Some members, such as Somalia and Djibouti, do not have an Arabic speaking population and does hardly belong to the sphere of Arabic culture. The states are also very diverse in size, and among the members are some of the poorest countries of the world (Somalia, Sudan and Mauritania), and some of the richest (Kuwait, Qatar and the United Arab Emirate). Islam is seen as a major factor of unity between them, but the way it is understood and practiced, and also the degrees of secularization, vary. To use these states as a base of comparison might therefore seem like a too wide generalization. However, the problems that arise around the implementation and coercion between Islam and the international human rights, are basically the same in most of the member states. The degree of development may of course vary from state to state, and also from time to time depending on what political branch is in power. For this reason I think it is possible to use the common terminology Arab States, when analyzing the fields of governmental action and human rights organizations in Muslim countries.

\subsection{Development on the governmental level}

\subsubsection{Commitment to the International documents on Human Right}

The first indications of an interest in the protection of human rights, both at a governmental and an intergovernmental level in the Arab states, can be traced back to the 1970s. This is probably due to mainly three factors. ${ }^{93}$ In the seventies the UN started to intensify its effort to

\footnotetext{
92 The Arab League was first established in 1945 and the present membership of the League is: Algeria, Bahrain, Djibouti, Egypt, Iraq, Jordan, Kuwait, Lebanon, Libya, Mauritania, Morocco, Oman, Palestine, Qatar, Saudi Arabia, Somalia, Sudan, Syria, Tunisia, United Arab Emirates and Yemen.

${ }^{93}$ An-Na'im Abdullahi A, Human Rights in the Arab World: A Regional Perspective, Human Rights Quarterly $23(2001)$ p 708
} 
pursue member states to ratify the two International Human Rights Covenants of 1966. The coming into force of these two documents also made it clear that human rights were now considered a matter of international concern. There was also, most importantly, a mounting appreciation for democratization and human rights protection within Arab societies during this decade. The first Arab states to ratify the two Covenants were Syria and Tunisia in 1969, closely followed by Libya in 1970 and Iraq in 1971. By 1999 nine more states had ratified the Covenants (Algeria, Egypt, Jordan, Kuwait, Lebanon, Morocco, Somalia, Sudan and Yemen). In 2003 Djibouti ratified. It is still worth noting that more than a third of the member states have not ratified any basic human right treaties at all. The CEDAW and the Convention against Torture has each been ratified by eleven states, mostly the same as those who ratified the two Covenants ${ }^{94}$

There is however, even among the states who actually have a good record of ratifying, a resistance to comply with the requirements of international supervision and accountability. The Optional Protocol for the International Covenant on Civil and Political Rights, that makes it possible for individuals to make complaints for violations of their human rights, has only been ratified by three Arab states (Algeria, Libya and Somalia). Many of the states that have ratified CEDAW have also done that with reservation in such crucial parts that it tends to undermine the whole idea of the convention. This is to be fair not a problem only in the Arab states. Other states, for example the US, have made reservations to several conventions. Among those states that have ratified the major treaties, there has been very little change in the national legislation to achieve their international obligations. Problems with getting these states to submit their periodic reports under the treaties in time have also occurred. The ambivalence among governments in the region to human rights is also reflected in the treatment of human rights NGOs, whose members often are harassed and their activities undermined or even prohibited.

\subsubsection{Governmental "human rights departments"}

Another development in the Arab World is the governmental creation of different forms of human rights departments, ministries or councils, all to at least appear to be committed to their international human rights obligations. Morocco did for example establish "the Advisory Council for Human Rights” in 1990, and also appointed a minister for human rights. Algeria

\footnotetext{
${ }^{94}$ CEDAW: Algeria, Djibouti, Egypt, Iraq, Jordan, Kuwait, Lebanon, Libya, Morocco, Tunisia and Yemen. The Convention Against Torture: Algeria, Bahrain, Egypt, Jordan, Kuwait, Libya, Morocco, Saudi Arabia, Somalia, Tunisia and Yemen.
} 
appointed a human rights minister in 1991, but the position was abolished again in 1992 and replaced by a governmental agency "The National Monitor of Human Rights". Tunisia has several human rights departments in addition to other ministries, such as Foreign Affairs, Interior, Justice and Social Affairs.

Different forms of human rights departments or councils are also found in Egypt, Lebanon, Oman, Bahrain, Kuwait and Yemen. ${ }^{95}$

\subsection{3 "Governmental” human rights NGOs}

A common response to international criticism of the situation of human rights organizations in the Arab world, has been for governments to be involved in creating or controlling their own human right NGOs.

The first organization of this kind was the "Iraqi Human Rights Organization", founded in 1970 to promote the views of the governing Bath-party. In 1975 the "Egyptian Human Rights Organization”, was established by people closely associated to President Sadat, leading to serious doubts about its credibility. In Tunisia the tension between the government and the independent NGO Tunisian League for Human Rights led to the establishment of another organization, "The Tunisian Society for Human Rights and Public Freedoms", on initiative of the government in 1987. One government that took it even further was that of Sudan, who not only banned the Sudan Human Rights Organization, but also replaced with its own organization with the same name. ${ }^{96}$ These organizations are not automatically "bad" organizations, but it of course affects the impartiality of an organization if it is tied to the government it is supposed to supervise.

\subsection{The local Human Rights movements in the Arab countries}

Besides the development made on a governmental level, the Arab countries have as most other countries, active NGOs that are very important in monitoring the situation and putting pressure on the establishment. When dealing with human rights in third world countries, and specifically the Arab countries, one can however easily get the impression that all work for implementation and supervising is made by western states, the UN or westerly based human rights organizations such as Amnesty International and Human Rights Watch. The existence and importance of local human rights organizations and other NGOs is rarely mentioned.

\footnotetext{
${ }^{95}$ An-Na'im, p 711

${ }^{96}$ An-Naim p 711
} 
There do however exist at least fifty local and regional organizations in the Arab countries. The importance of these, especially in the work of spreading the ideas of human rights among the people of their countries, should not be underestimated ${ }^{97}$. But the Muslim human rights organizations suffer from several problems of both internal and external nature.

One common perception is that governments of developing countries are more responsive to international pressure, than to pressure from local NGOs. This leads to a tendency of international human rights NGOs monitoring human rights violations in developing countries with help of local NGOs, but their findings mostly gets published in Europe and North America in order to influence western governments to put pressure on the government of the

development country. ${ }^{98}$ The pressure from regional groups on their own government becomes somewhat secondary. Another problem is that local NGOs often get most of their funding from, and seek publicity for their activities in the West, instead of from within their own countries. This results in accusations of local organization following a "western" agenda and they are seen with skepticism from especially Islamic movements. This is a large disadvantage when a dialogue on the local level is an absolutely necessary step towards a better human rights climate.

According to An-Na'im, an important step to achieve a larger acceptance and compliance with international human right standards, is overcoming what he calls the human rights dependency of the regional organizations. The purpose of this is not to end the observations and interference of international NGOs, but to improve the coordination and cooperation of the regional and local NGOs, to strengthen their position and facilitate their work.

\subsubsection{Independent Human Rights NGOs}

When referring to regional NGOs of the Arab world, the definition does not only include the organizations operating inside the countries, but also some of the organizations working in exile. One problem that might occur with the exile organizations, is establishing whether the interest of their members is to actually promote human rights, or if they're mainly driven by political programs of for example an opposition party unable to work within the country. Since many of the Arab states are governed by non-democratic regimes, these ambiguities are common also among national and regional organizations.

Human Rights NGOs in a strict sense (trying to exclude those with a political motive), has existed in the Arab world since the 70 s and began in the countries that had a relative degree of

\footnotetext{
${ }^{97}$ Ibid, p 730

${ }^{98}$ Ibid, p 702
} 
political pluralism. The first established organization was accordingly the Moroccan Human Rights Organization, registered in $1972 .{ }^{99}$ In 1977 this initiative was followed by the establishment of the Tunisian League of Human Rights and the Egyptian organization "Society of Supporters of Human Rights", with branches both in Cairo and Alexandria. The first sign of a regional cooperation on a non-governmental level came in the $80 \mathrm{~s}$ with the establishment of the AOHR (the Arab Organization of Human Rights). The initiative for the establishment of an "umbrella"-organization, that could coordinate strategies for smaller local NGOs, emerged already in 1971 on the suggestion of the Iraqi Human Right Organization (mention earlier among the government influenced HR-organizations). A preparatory committee was set up and a draft for a charter was made, but due to differences about the new organization's structure the idea never led to any practical result. In 1983 it was revived by a group of Arab intellectuals in Tunisia, and in 1984 the founding conference was held in Limassol, Cyprus, as it at the time it was impossible to hold it in any Arab-state. The AOHR has had its headquarters in Cairo since the beginning, but it wasn't until 1993 the organization was officially recognized by the government and allowed to hold one of its general meetings there. ${ }^{100}$ According to the Charter of the AOHR, the goals of the organization are:

- to endeavor to protect the human rights of all persons, in accordance with international standards

- to raise the awareness of the Arab people of their rights

- to cooperate with other organizations working in this field ${ }^{101}$

The AOHR also publishes annual reports on the statues of human rights in the Arab world, a series of bulletins and a research journal. However, critics of the AOHR claims that the organization has failed in large parts, especially in being an umbrella organization and coordinating strategies and common agendas for smaller NGOs in the area. ${ }^{102}$

In the midst $80 \mathrm{~s}$ several other significant HR-organizations in various Arab countries and among Arab activists in exile, mainly in Western Europe, were founded. Examples in the region are the Egyptian organization for Human Rights from $1985^{103}$ and the Sudanese

\footnotetext{
${ }^{99}$ An-Na'im, p716

${ }^{100}$ Although Human Rights organizations have been more accepted, one example on the personal risk that activists still endure is the Libyan opposition figure and member of the Boars of Trustees of AOHR Mansour AlKikhya "disappeared" in Cairo just after the meeting in 1993 and his whereabouts are still not know by either Egyptian or Libyan authorities

${ }^{101} \mathrm{An}-\mathrm{Na}$ 'im $\mathrm{p} 717$

${ }^{102}$ Ibid

${ }^{103}$ Although former problems with registration in Egypt, there is since 1999 a new statue regulating NGOs. The Egyptian organizations can now be granted tentative approval, but formal approval is depending on regulations
} 
Human Rights Organization founded the same year, but since the military coup in 89 working from outside the country. Both these organizations have suffered problems with official registration in their countries, a problem that also applies to the Kuwaiti Human Rights organization. But there are also many Arab states in which the NGOs are able to officially register and thereby work within their countries (Lebanon, Tunisia, Algeria, Morocco, Jordan and Yemen). There was an attempt in 1997 to found a network of Arab activists - the Arab Working Group on Human Rights. At first it only had the purpose of working with the situation in Algeria, but was gradually expanding to other regional issues. The organization did unfortunately terminate itself in 2001, due to operational difficulties. ${ }^{104}$

From this review of human rights NGOs in the Arab world it is pretty clear that the growth and development of these are largely restricted to the North African region, a consequence of better possibilities to official registration. On the Asian side of the Arab world, the governments, both traditional and secularized, have a stronger tendency to counteract human rights activists. For example, in both Sudan and Saudi Arabia HR-activists have been harassed or even detained, and organizations have been forced to operate in exile. As mentioned before, lots of the exiled NGOs consist of politicians in opposition, and have ulterior motives other than protecting the rights of the people. Other governments who support their agenda, and have an interest in undermining the government of the NGOs country of origin, are therefore often keen to host exile organizations. For example, Syria hosts an Iraqi committee for human rights and Iraq does the same for a Syrian organization. There are however exileorganizations which are generally accepted by observers as legitimate human rights NGOs (ex a Syrian organization in Paris and a Bahrainian in Denmark). ${ }^{105}$

The most recent attempt to create an organization for cooperation on a regional level was the Arab Human Rights Movement, who held their first international conference in Casablanca in March 1999. It was organized by the Cairo Institute for human rights studies, in collaboration of the Moroccan Organization for Human Rights. The conference was attended by about 100 representatives from different human rights groups from across the Arab world, and resulted

\footnotetext{
to be issued under the status ( Law No.153 of 1999). The law however also gives the Minister of Social Affairs the right to, without motivation, prohibit any registered association from receiving foreign funding, something that may limit the organizations activities severely. Remarkable about Egypt is also that they also have more than specialized human right NGOs, such as the Center for Women's Rights and Center for the Human rights of prisoners, just to mention a couple of them.

${ }^{104}$ An-Naim, p 718

105 An-Naim, p 719
} 
in the "Casablanca Declaration of the Arab Human Rights Movement". The declaration set out to deal both with the problem of the acceptance and implementation of human right in the Arab world, and the problems of the regional human rights NGOs. It also called for a revision of the Arab Charter of human rights, which according to Bahieddin Hassan, the director of the Cairo institute, was the worst document ever issued on human rights. The Casablanca declaration is critic against the UN for not representing all regions of the world equally, and the double standards employed by most notably the US when it comes to applying international law differently in various conflicts. It also criticizes the Arab government for manipulating the patriotic sentiments in their countries to avoid complying with international human rights standards. Iraq, Libya and Syria are further accused of total ignorance of basic human rights, while the "back-pedaling" in more secular states such as Egypt, Tunisia, Yemen and Jordan is regretted. Morocco is the only country getting positive critic for relative progress in human rights questions. The conference also was alarmed by the continued lack of a modern legal structure that might facilitate the implementation of human rights in many Arab countries. The Arab governments are further encouraged to reform their legislation, especially in the field of the right to freedom of expression. The Islamist groups aren't either spared criticism, and are accused of violence and intellectual terrorism. Apart from this general, and most of the time rightly-deserved criticism, the Arab Human Rights Movement also sets out goals for itself and the local human rights NGOs, stressing the importance of among other things the organizations independence from political parties and the improvement of the cooperation between the organizations. The organization had a second conference in 2001 around the theme of human rights education and dissemination. ${ }^{106}$

\subsubsection{The problems of Arab human rights NGOs}

The NGOs in the Arab world are, as mentioned earlier, suffering from many different problems and complications that are severely limiting their activities and possibilities of development. Some of these may just be "infant-diseases", as many of the organizations still are relatively new, and can be solved by better organization and enhanced cooperation between different organizations. But there are also political and cultural obstacles, both within the countries and in their international relations, which are considerably harder to deal with. An-Na'im, in his article Human Rights in the Arab World, 2001, summarizes the general obstacles as due to seven factors or processes. I've decided to use these, although somehow

\footnotetext{
${ }^{106}$ Human Rights Watch World Report 2001: Middle East
} 
mixed with my own thoughts, since I think they in a relatively objective way points out what needs to be considered or improved in order to facilitate a change in the human rights climate in the Arab (and probably also in other Muslim) states:

1. Problems with registration and official recognition. Many organizations are consistently denied official registration and systematically harassed by the majority of the governments of the region. The only government that has declared to permit full registration and legal operation, at least for some human right NGOs, is that of Egypt. This is a promise still waiting to be fulfilled.

2. "Unresolved conceptual difficulties". As an example of this An-Na'im mentions the lack of a strong civil society, aware of its rights and with an effective organization to protect them. This is mainly a post-colonial problem, making it a lot easier for the governments to disregard human rights without being questioned. Another type of conceptual difficulty for the Arab human rights NGOs, is how to deal with the Islamist movement. Should they respect the rights of these groups regardless of if they promote a society where not everybody's rights would be treated the same way (ex women and religious minorities), or is it permissible to restrict human rights if the mean is to achieve a democratic society?

3. Distrust of the international community. The insecurity and the sense of being treated unjustly by the international community, is an obstacle for popular acceptance of human rights, as they still are seen as a western concept. This distrust is hard to argue with, especially after the way the Israeli-Palestinian conflict has been handled all the way since 1948, but with emphasize on the later years of occupations and group punishments of Palestinians remotely related to suicide bombers. Europe, but mainly the US have had a tendency to support opposition groups to achieve a change of regimes, not considering (or caring..) whether the new regime is in any way better or more democratic than the former one. The most flagrant example is the former American support of the Talibans in Afghanistan. This is also a source of skepticism. The most recent example of western interference is the Iraqi conflicts. It is no coincidence that the Arab people (or anyone else for that matter..) have difficulties understanding how International Law doesn't seem to apply equally to all states, and whatever the motives of the last invasion of Iraq was the justification of it seems rather vague. The list could be made much longer, but the point is that an irregular use of international law, dependent on which country one is dealing with, will only increase the anti-western currents we see today. This leads to a more difficult situation for those who work for a more democratic society and human rights. Arab 
human rights advocates are often described in popular discourse as "traitors", trying to impose Western values and institutions. Western governments are associated with unjust politics.

4. Lack of an internal philosophical and cultural justification for human rights principles. The concept of universal human rights has its roots in Western philosophy and culture. They are consequently often considered part of a neo-colonial hegemony, and there is a tendency to emphasize on confronting the West rather than working on internal issues of political and social transformation. A severe lack of tradition of civil activism and regional NGOs is also a problem.

5. The weakness of Arab human rights NGOs and the relationship with international organizations. Human rights in this part of the world are protected through economic or political pressure from the West, rather than through internal activities of civil society. This among other factors lead to serious differences of opinion between local and international NGOs regarding for example humanitarian intervention, economic sanctions and political conditions in economic and military aid. The influence of international organizations is also limited in developing countries, since many violations fall outside the scope of international law. Militant Islamic groups are for example not subjects of international law, as they are not states, and they can consequently not be held accountable for their human rights violations. Human rights law is also meaningless in "collapsed states" like Somalia, and states in civil war like Algeria. The relationship between international and local organizations is also complicated by lack of coordination and cooperation. Conflicting priorities has a tendency to lead the marginalization of the local organization that doesn't have as much financial or political support.

6. The politicization of Arab Human Rights movements. As mentioned earlier many of the local human rights organizations are, at least to begin with, dominated by one certain ideological group. This alienates people who might believe in the same cause but from a different political or religious perspective. It has also in many cases, like for example the $\mathrm{AOHR}$, led to internal rivalries for leadership and difficulties in agreeing on how to address major crises like the invasion of Kuwait. These internal struggles for power do serious damage to the credibility of the organization, both in the eyes of international organs, as well as the public in the Arab countries. Another dilemma that has appeared is the strong emergence of Islamic activism during the last couple of years. To not loose their already weak public support, leaders of human rights organizations are afraid to be branded anti-Islamic. It therefore becomes difficult for them to challenge contradictions 
between international human rights standards and Sharía based principles, such as the rights of women and non-Muslims.

7. Institutional weakness. This aspect is linked to several of the other above-mentioned factors, such as the lack of recognition and the constant harassment of human rights activists. The lack of an "umbrella" organization, as the AOHR failed to be, also leads to a difficulty in showing a united front against authorities and international institutions. The inability for Arab HR organizations to develop strategies for negotiating with the governments of the region is also a problem.

The importance of dealing with these problems of the regional NGOs really can't be stressed enough. If the goal is to achieve a general understanding and tolerance of human rights among people in general, not only on a governmental level, and in a longer perspective educate people of their rights so that they themselves can claim them from the often not very democratic regimes in the Arab world, the work of the local organizations is invaluable. Since they are a part of the culture and traditions with which the international rules sometimes clash, their comprehension of problems in the implementation of these rules is wider than that of international human rights NGOs, and their possibility to find a tolerable solution is consequently much bigger.

\subsection{Islamic Fundamentalism and Human Rights}

Several of the complicated issues the regional human rights NGOs deal with, are in some way connected to the antagonism between fundamentalists and more liberal Muslims. I therefore thought it would be interesting to establish whether there exist any fundamentalist human rights movements. First we however have to define fundamentalism. The word has been given an undoubtedly negative meaning lately, and in media it is often limited to the most extreme traditionalist movements in Islam, and also wrongly connected to terrorism. For this reason I will instead use the term "political Islam". Political Islam includes a diversity of movements advocating and practicing Islamic politics, and they all have an Islamic agenda. The goal is rarely trying to create a legal and political system entirely based on Sharía, but to implement the ideas of Islam to different degrees. Political Islam exists both in power and in opposition in different countries in the Arabic (Islamic) world. The best known example of Islamists in a governing position is the regime in Iran. Opposition movements or parties exist probably in 
all Islamic countries where they're not in a governing position. Many human rights activists in the region are of the opinion that human rights can under no circumstances be combined with political Islam. Others claim that although members of fundamentalist organizations are fighting for human rights, the interest is only to protect the rights of their own members, who in many countries due to being opposed to a governing regime are subject to harassment and violation of their rights. ${ }^{107}$ Among groups of secularized intellectuals it is even a dilemma whether to grant fundamentalists the same rights as everybody else, since this potentially may lead to them seizing power, creating a system where the rights of some will be denied. Obviously this is a serious dilemma. Universal human rights are not supposed to depend on the consequences of granting them to non-democratic groups, as this would undermine the whole moral perspective of universality.

Within the political Islam movements, as in any other ideological movements, a variety of different standpoints on human rights issues can be found. The National Islamic Front (NIF) in Sudan is one example of an Islamic movement whose main ideologue rejects human rights, considering them a product of positivist and materialist Western jurisprudence. Hassan AlTurabi from the NIF, the only member of the organization who has written about this ideology, describes an ideal Islamic society based on liberation from positivist and materialist chains, and with absolute loyal to God. Such a society would not need any rights invoked from an authority ${ }^{108}$. Sheik Rached Al-Gannouchi, is the leader of the Tunisian An-Nahda political party (an Islamic party). His opinion is often quoted in the debate about human rights and Islamic fundamentalism. He is not directly dismissing human rights as a concept, but he does express the common opinion that it is an issue over which secularists exercise a monopoly. ${ }^{109}$ This is fueled by the fact that leftists, that are traditional enemies of the Islamic trends, lead most human rights organizations. The Islamic fundamentalists, or advocates of political Islam, do however suffer from partly the same problems as the human rights activists. In many countries, the Islamist are harassed and persecuted, and their human rights are often violated. There is however a skepticism towards them among the advocates for human rights. Even in cases where they might support human rights, they are rarely taken seriously or allowed to participate in the more established human rights NGOs.

\footnotetext{
${ }^{107}$ Hicks Neil, Does Islamist Human Rights Activism offer a remedy to the crises of Human Rights implementation in the Middle East? Human Rights Quarterly 24 (2002) p 366

${ }^{108}$ Abdelmoula Adam M., The fundamentalist agenda for Human Rights: The Sudan and Algeria, Arab Studies Quarterly, Winter 96, Vol 18 Issue 1, p5

${ }^{109}$ Hicks Neil, Does Islamist Human Rights Activism offer a remedy to the crises of Human Rights implementation in the Middle East? Human Rights Quarterly 24 (2002) p 369
} 
But human rights activities exist within the Islamic movements too. Since there are obvious contradictions between human right standards and a strict Islamic agenda, these movements are suspected of being less serious or having ulterior motives. They also suffer from the problem in claiming they promote human rights, but not being able to offer the same protection for everybody. In Iran there are for example Islamist women's rights organizations, working very actively for a reinterpretation of the Qur'an, to achieve more equal rights for women. Since they still agree with many of the rules discriminating against women, they however fail to protect the rights of secular women. The secular women still have no choice but to apply to rules set in the name of a religion they don't belong to, and which highly limits their rights and freedoms. ${ }^{110}$ One country, in which there has been an increasing interest in human rights connected to movements with Islamic background, is Egypt. In Egypt there has been a methodical governmental suppression of organizations and institutions during the last decade, for example changing laws to make it more difficult to register associations. In the early 90s professional associations like the Medical syndicate and the Engineers syndicate, which both are organizations mainly controlled by the Muslim Brotherhood, formed human rights committees. They began to campaign on behalf of their members, who suffered from for example persecution on political grounds or in other ways got their individual rights violated. The Islamic influence in the Bar association, traditionally known for supporting human rights, has also increased. This development towards a higher percentage of Islamic members in the human rights activism could in later years be seen in several organizations in Egypt. In the EOHR (Egyptian Organization of Human Rights) there are even persons associated with political Islam as members of the executive board. It is however hard to reach any conclusion to whether these attempts of Islamic human rights activities were seriously meant, or as critics claimed only in their own interest and as a forum for opposition politics. The syndicates, who were the major venues for Islamic human rights activities, fell victim to state repression and most leaders where sentenced to prison in 95-96. This stagnated the development, and the true nature of their commitment to human rights remains hard to analyze $^{111}$.

The most interesting example of an explicit Islamic human rights movement that I have come across in my research is the Turkish "Mazlumder" movement. Turkey is quite different from the Arab states that I mainly have been using as objects of discussion earlier in this essay. It

\footnotetext{
${ }^{110}$ Afshari, p 251

${ }^{111}$ Hicks, p 372
} 
has been, at least in theory, a secularized state since the modern Turkish states was established in 1923 by Mustafa Kemal Ataturk. Still, the Turkish State is not neutral in the question of religion. There is for example a state-approved version of Islam, and the Imams are employed by the state. ${ }^{112}$

In difference to Egypt, Turkey usually has at least one Islamist party that is allowed to participate on the political scene (although from time to time banned, but the often re-opened under a different name). The Refah (welfare) Party served as part of a governing coalition, after getting over $20 \%$ of the votes, which made them the largest party in 1995-96. Their leader Necmettin Erbakan became the countries first Islamist Prime minister. The Erbakan government was however removed after military pressure, and the party, who also had been very successful in local elections and was controlling both Istanbul and the capital Ankara, was banned for being a threat to the secular state. The Fazilet (virtue) Party emerged in its place to be banned in 2001 and replaced by two new Islamist parties. ${ }^{113}$ The Islamist parties have not had an outspoken human rights agenda. They have been involved in certain issues with a human rights connection, like calling for a liberalization of the laws restricting freedom of expression on the issue of secularism, and an end to the banning of parties. Critics of course claims that they only care about human rights when it is in their own interest, but the Islamist party probably doesn't show more or less interest in human rights than any of the other established parties. ${ }^{114}$ Beyond the political scene there is however an ongoing development of associations promoting Islamic liberalism. Although these groups are no typical human rights movements, they have played an important role in bringing the human rights concept into the contemporary Islamic discourse. Examples of Islamic Liberalistic associations in Turkey are the Nurcu movement, associated with the teachings of Said Nursi, and the Fethullah Gulen, a more nationalistic movement. The intellectual climate in Turkey is in general more open to the ideas of liberalism and human rights than in for example Egypt. In 1991 an organization, the earlier mentioned organization the Mazlumder (The Organization of Human Rights and Solidarity for Oppressed People) was founded. ${ }^{115}$ This organization, which might be seen as proof of a possible Islamist human rights activism, was founded by a group of activists with the roots in the political Islamic movements. They set out to defend the human rights of everybody, regardless of political affiliation or religious preferences, implicitly criticizing other organizations for not doing so. Mazlumder has a good record of

\footnotetext{
${ }^{112}$ Ibid p 374

${ }^{113}$ Hicks p 376

${ }^{114}$ Ibid, p377
} 
establishing successful working relations with other human rights organizations, and is now one of the largest human rights NGOs in Turkey. It is also among the NGOs that the government cooperates with ${ }^{116}$. In its documents, the Mazlumder shows a universalistic vision of human rights, compatible with international standards. An example from their information sheet "On the side of all oppressed against all oppressors":

\footnotetext{
"Mazlumder believes that human rights are universal, and that the source of human rights is the fact that individuals were created as human beings. Thus, natural law divine law - constitutes the foundation of human rights. Mazlumder does not support the idea that there are either cultural or regional differences in basic human rights."
}

The movement has according to its leader Yilmas Ensaraglu helped the development, and broadening the sensitivity to human rights among religious people and the political right. $\mathrm{He}$ does however admit that the organization still has problems overcoming the image opposed upon it by people who are not exposed to their work, meaning that no matter what they do they are still suspected of being a fundamentalist group working only in their own interest. Still, Mazlumder tries to be an alternative for Muslims who believe that political Islam and human rights are not an impossible combination, and as mentioned earlier they do have a very good record of cooperating with a range of groups that are not in associated with the political Islamic trend ${ }^{117}$.

\section{Conclusion}

Many times during the process of writing this essay, I've felt compelled to change the question I'd be answering from being whether Islamic law is compatible with universal human rights, to whether universal human right are a mainly Western idea, and if it in that case is within our right to, without compromise, claim supremacy for them over other conflicting rules, regardless of their foundation or legitimacy. I however made the decision to not make this about the justification of the universality of human rights, and instead chose to just presume them as a reasonable standard most individuals would benefit from being granted. I do still think that it is an important point to keep the discussion of cultural

\footnotetext{
${ }^{115}$ Ibid, p 378

${ }^{116}$ Ibid, p 379
} 
relativism open, since there are obvious problems in the practical aspect of trying to implement human rights in parts of the world outside our western sphere. I think we have to acknowledge and respect that other cultures might need to find their own way of justifying human rights, to be able to give them an impact on people on a grass-root level. It is also very important to keep in mind the strength of religion in large parts of the world. We should not underestimate the problem that it constitutes to implement and motivate universal human rights, since religious values as we have seen examples of in Islam, does not always comply with them. Whether or not we consider "our" universal human rights as the right minimum standard to set for the protection of the individual, we have to accept the existence of other standpoints to be able to solve the practical problems surrounding human rights issues in many third world countries. The Islamic human rights documents are a very good example of how, even though in some of them the will to compromise exists, some religious values and rules will make it almost impossible to completely reach the standard set by the UN. Rules on blasphemy and apostasy will in an Islamic state inevitably constitute a problem for the freedom of expression and freedom of religion. Also the fact that women have a different role in Islam, which can't be changed even by a severe reinterpretation of the Qur'an, constitutes a breach of international rules. But even though the documents where direct references to the Sharía are made does not constitute sufficient protection for human rights, it is important to appreciate that at least in later documents, as the Cairo Declaration and the Arab Charter, an effort is made on an intergovernmental level to adjust to UN-standards. Even if the result is not always fully satisfying from a western standpoint, one must remember that the mere existence of a discourse is a progress in some of the Arab countries.

The Islamic states record of ratification of international human rights treaties also leave a lot left to ask for. On one hand the members of the OIC that have not ratified any of the two Covenants represent "only" thirty percent of the total of states that stand outside these important human rights treaties. But many of the non-ratifying Islamic states are countries with rather large populations such as Saudi Arabia, Pakistan and Malaysia, while most of the remaining states with a poor record of ratifying are tiny Caribbean or Pacific islands with small populations. It is consequently reasonable to say that the Islamic countries in reality represent a larger problem when it comes to non-ratification than statistics may show. The combination of this, and the Islamic human rights documents not fully complying with

117 Mazlumder's web-page; www.mazlumder.org 
international standards and therefore failing as an alternative way of achieving sufficient protection, makes it impossible not to conclude that the Islamic countries, even if maybe unfairly seen as a collective, according to UN standards have a lower degree of protection of human rights.

It is also important to notice that the Islamic human rights documents mentioned earlier, even though some of them represent descent attempts to create an Islamic alternative to the international equivalence, have not been ratified in any of the Islamic or Arabic states that have produced them. In practice, their impact on the human rights situation is therefore limited.

International institutions and other governments at the moment mainly make the pressure of imposing human rights in Muslims countries. One interesting aspect of this is that the states that have the worst records of ratification of UN documents, such as Saudi Arabia, Oman and the United Arab Emirate, seem to be less in focus than for example Iran or Iraq, who at least on paper have rather good records of ratification. This can hardly be explained by the former countries having a better situation when it comes to human rights organizations, or less violations of human rights. The lack of democracy and the situation of for example women or religious minorities are just as bad, if not worse, in for example Saudi Arabia, than in any other Arab country. I'll leave it unsaid whether this has a connection to the richer Arab countries being important oil-producers, but the consequence is as always that the credibility and the legitimacy of the western countries concern in the human rights situation in the Arab world may be jeopardized. The indictments for implementations must in larger part come from the people of the Muslim countries to start with, but if and when pressure comes from other foreign parties, it is of great importance that it is made in a way that seems "fair" and proportional to the people of the region. If large discrepancies exist in the treatment between countries, the justification of international law as anything else than random and ruled by political interests, rather than actual concern for protection of individuals, is precluded. One may also consider that the ratification of UN documents is not always the best measurement of a country's devotion to human rights. Many states might be parties to conventions without actually applying their rules in reality. Another problem is that states are not the only violators of the rights of its citizens. For example fundamentalist movements or rebel groups often commit violations. With those violations, whether or not a state has signed the Bill of Rights becomes irrelevant. 
When it comes to the specific problems Islamic countries have with the adjustment to international human rights, different solutions are being suggested in the debate among Muslims themselves. Reformists claim that reinterpreting the Sharía would be the only way to adjust Islam to the modern world. But the call for reformation seems to mainly come from Muslims in exile in the west. In most Islamic countries, there has instead been an increasing support for an "Islamization", where the society and legal systems are more adjusted to Sharía and religion in general. Political systems such as in Saudi Arabia and Iran are good examples of this kind of politized Islam. There does not seem to exist any wider support for reformation among the people in the Arab countries, which in practice makes it a less viable solution. The theories on why the idea of a stricter Islamic society appears to appeal to a lot of people in the Middle East are many. I think there is little doubt that the polarization between east and west, caused by the political tension in the region, leads to the anti-western currents that often pushes people to take a more extreme position to the opposite side than they would normally do. Fighting against a common external enemy also makes people more inclined to forget about their own rights, and focus solely on the preservation and defense of their culture. The dissatisfaction with the international community is another source of concern, since it leads to an increased feeling of isolation, and conviction that western values are imposed without any consideration to local customs or beliefs.

An effort to try to bring the Islamic world closer to our western human rights through reinterpretation of the Qur'an and Sharía, would only work if it had a major support from the people who would be affected by such a change. As Bassam Tibi expresses it; "..the accommodation of Islam to cultural modernity must take place from the inside and be carried out by Muslims themselves." 118 Since at the moment no broad support for reformation among Muslims seems to exist, at least not in the Arab countries, the chance of any real change in this manner appears unrealistic to me.

The other possibility often mentioned to solve the conflicts between Islamic law and international human rights, is the liberal idea of secularization. With my limited knowledge of Islam I can see how a reinterpretation of the Sharia would facilitate the adjustment to international standards, but I think that the only way to actually be able to adjust fully to international law would be secularization. Since the universal human rights are theoretically based in secularization between state and religion, the religious values are going to be hard to

\footnotetext{
${ }^{118}$ Tibi, p 156
} 
combine with them in some aspects. As I see it, a system based on the Sharía, even in the case of a rather liberal interpretation, will never be completely compatible with the standards of universal human rights as defined by the UN. The problem with segregation between state and religion is on the other hand identical with the complexity of reinterpretation (reformatism). As long as there is no support at a grass root level, the organic process that such a large change of society would demand is not possible.

In practice the problem of a human rights adjustment in the Islamic world, and the Middle East in particular, is even bigger and more complex than in theory. The local and regional human rights NGOs suffer from huge difficulties, from being prohibited to register their organizations and being harassed by the authorities, to being seen with skepticism from the people of their own countries for being traitors trying to impose western values. The international organizations are met with an even larger skepticism, and have the disadvantage of not being able to completely appreciate the cultural differences, since they are not a part of either the culture or religion of the region. As long as human rights are seen as a western set of values, the growing anti-western currents, caused by political double standards and the obvious abuse of international law during the latest invasion of Iraq and in Israel, constitute an obstacle for the acceptance of human rights in these countries. I think it is important to get the human rights activity down to a lower level and try to support an increased knowledge and understanding among "normal" people of what rights for the individual the universal human rights signify. If the discussion is only carried out on a governmental level, or by academic scholars, the acceptance will never reach the local level, and human rights will only have a theoretical not practical relevance. I also think that most people, if rightly informed about individual human rights, would not be opposed to the concept regardless of what culture or religion they belong to. If pressure is put on the governments or undemocratic regimes from their own people, and not only by foreign bodies, they would probably have to make a larger effort to adjust their legal systems and grant the individuals the rights they deserve. It is also very important that international human rights NGOs cooperate with the regional organizations to a greater extent, to help achieve increased knowledge of human rights among the people of the Arab world.

The most important thing as I see it, is however for all parties, to by increased knowledge and understanding try to deal with the problems cultural and religious differences bring. Compromising must be done without blindly judging the opposite side as the one being 
wrong, and by trying to see past old prejudice and political history. The implementation of human rights needs to be an organic process, where consideration is taken to the fact that international law after all basically is European law (and North American). International law is not culturally sensitive, and there is little room for regional variety based in the actual differences existing. New states are automatically bound by already existing rules, of which many are based back in the times when large parts of the world were still colonized. The idea of an international community rests on the assumption of a substantial cultural consensus on international law, and I think we have to at least start with admitting that this assumption is wrong. In many parts of the world outside our western cultural sphere, historical anchorage to the development of international law is lacking, as well as philosophical grounds of their own to explain the idea behind universal human rights. As stated earlier, human rights are derived from Western sources and philosophies, and it is not always easy for people raised in other cultures to just blindly accept or understand our justification of them. Especially in the parts of the world where religion has a strong position, our secularized idea of human rights not granted by a God, easily becomes secondary to the rights that purposively are of divine source. This does not necessarily mean that we should stop our intents to spread an implementation of human rights in parts of the world where the understanding for them as a concept is not obvious. But we might have to revaluate the way we do it - if not we are risking a situation where human rights becomes just another part of what often is seen as imperialism through political pressure. All real change must come through a combination of input from international organizations, and local adjustment based on an actual understanding and acceptance of the international rules and their extraction. It is also possible that the support for human rights would increase in third world countries, if the importance of later generations of rights, such as the collective rights to for example economic and social development, would be more in focus. These rights are obviously of more interest in underdeveloped countries, but often get a lower priority in the debate of human rights in the West.

To conclude, the Islamic parts of the world include a variety of countries that are secularized at different levels, and where the Islamic interpretations may be very miscellaneous. There is no way getting around that large problems with violations of rights of women or religious minorities exist in many of these countries, whether or not this is due to religion. A strict interpretation of the Sharía does also leave room for restrictions in some of the rights we consider universal, and this should not be defended. We must however take into account that Islam is the religion of millions of people in the world. To just dismiss the influence it has on 
them, and to not understand the complications that inevitably follows when trying to force them to embrace rules, that in their point of view might go against the will of God, is not only disrespectful but also futile. This is the main reason to why all implementation of human rights, should be done in cooperation with local organizations that know how to help facilitate the process, through for example education of the affected people. This will eventually help the adaptation of the concepts of human rights, into their different religious and cultural context. 


\section{Literature}

\section{Books;}

Bogdan Michael, Komparativ Rättskunskap, , 1996 Nordsteds Juridik

Caney Simon and Jones Peter Human rights and Global Diversity, , Frank Cass and Co Ltd, London 2001

Dalacoura Katerina ,Islam, liberalism and human rights, I.B Tauris Publishers, New York 1998

Donally Jack , International Human Rights, Westview Press 1998, Second edition

Esposito John L. Islam - den raka vägen, Studentlitteratur 2001

Mayer Ann Elisabeth, Islam and Human Rights - Tradition and politics, Third edition 1999, Westview Press, Boulder Colorado

Nordberg Michael, Profetens folk, Tidens förlag, Stockholm 1988

Ruthven Malise, Islam in the World, second edition 2000, Oxford University Press, NY

Schmale Wolfgang Human Rights and Cultural Diversity, Keip Publishing Goldbach, Germany 1993

Steiner \& Alston, International Human Rights in Context, Oxford University Press 2000, Second Ed

Tibi Bassam Islam between Culture and Politics, Palgrave NY 2001

Tergel Alf Human Rights in Cultural and Religious Traditions, , 1998, Acta Universitatis Upsaliensis, Uppsala Theutenberg Bo J, Folkrätt och säkerhetspolitik, Nordstedt 1986

The Holy Qur'an, translation Abdullah Yusuf Ali, Quatar National Printing Press, 1946

\section{Articles;}

Abdelmoula Adam M, The Fundamentalistic agenda for human rights - The Sudan and Algeri, Arab Studies Quarterly, Winter 96, Vol 18 issue 1

Afshari Reza, Human Rights in Iran -the abuse of Cultural Relativism, University of Pennsylvania Press,Philadelphia

An-Na'im Abdullahi A, Human Rights in the Arab World: A Regional Perspective, Human Rights Quarterly 23 2001

Baderin Mashood A., Dialogue among civilizations as a paradigm for achieving universalism in international human rights - a case study with Islamic Law, Asia-Pacific Journal on Human Rights and the Law, Volume 2, Number 2

Hassan Riffat, On Human Rights and the Qur'anic Perspective, Swidler A (ed) Human Rights in Religious Traditions, NY 1982, Pilgrim Press

Hicks Neil, Does Islamist Human Rights Activism offer a remedy to the crises of Human Rights implementation in the Middle East? Human Rights Quarterly 24

Tabet Koraytem , Arabic Islamic Developments on Human Rights, Arab Law Quarterly 2001, Kluwer Law International Netherlands 


\section{Official Documents;}

UN Documents:

The Universal Declaration of Human Rights (UDHR) 1948

The International Convenant on Civil and Political Rights (ICCPR) 1966

The International Convenant on Economic, Social and Cultural Rights (ICESCP) 1966

The Convention of Elimination of Discrimination against Women (CEDAW) 1979

Other Human Rights Documents:

Human Rights in Islam - A. A. Mawdudi 1975

The Universal Islamic Declaration of Human Rights (UIDHR) 1981

The Cairo Declaration on Human Rights in Islam 1990

The Arab Charter of Human Rights 1994

Human Rights Watch World Report 2001: Middle East

\section{Links;}

H.A.R Gibb "The Shari'a" (www.answering-islam.org)

The Organisation of the Islamic Conference (www.oic-oci.org)

The Arab League (www.arableagueonline.org)

Wikipedia Encyclopedia (www.wikipedia.org.wiki)

Mazlum Der (www.mazlumder.com) 


\section{The Cairo Declaration on Human Rights in Islam, 5 August 1990.}

The Nineteenth Islamic Conference of Foreign Ministers (Session of Peace, Interdependence and Development), held in Cairo, Arab Republic of Egypt, from 9-14 Muharram 1411H (31 July to 5 August 1990),

Keenly aware of the place of mankind in Islam as vicegerent of Allah on Earth;

Recognizing the importance of issuing a Document on Human Rights in Islam that will serve as a guide for Member states in all aspects of life;

Having examined the stages through which the preparation of this draft Document has so far, passed and the relevant report of the Secretary General;

Having examined the Report of the Meeting of the Committee of Legal Experts held in Tehran from 26 to 28 December, 1989;

Agrees to issue the Cairo Declaration on Human Rights in Islam that will serve as a general guidance for Member States in the Field of human rights.

Reaffirming the civilizing and historical role of the Islamic Ummah which Allah made as the best community and which gave humanity a universal and well-balanced civilization, in which harmony is established between hereunder and the hereafter, knowledge is combined with faith, and to fulfill the expectations from this community to guide all humanity which is confused because of different and conflicting beliefs and ideologies and to provide solutions for all chronic problems of this materialistic civilization.

In contribution to the efforts of mankind to assert human rights, to protect man from exploitation and persecution, and to affirm his freedom and right to a dignified life in accordance with the Islamic Shari'ah.

Convinced that mankind which has reached an advanced stage in materialistic science is still, and shall remain, in dire need of faith to support its civilization as well as a self motivating force to guard its rights;

Believing that fundamental rights and freedoms according to Islam are an integral part of the Islamic religion and that no one shall have the right as a matter of principle to abolish them either in whole or in part or to violate or ignore them in as much as they are binding divine commands, which are contained in the Revealed Books of Allah and which were sent through the last of His Prophets to complete the preceding divine messages and that safeguarding those fundamental rights and freedoms is an act of worship whereas the neglect or violation thereof is an abominable sin, and that the safeguarding of those fundamental rights and freedom is an individual responsibility of every person and a collective responsibility of the entire Ummah; 
Do hereby and on the basis of the above-mentioned principles declare as follows:

\section{ARTICLE 1:}

(a) All human beings form one family whose members are united by their subordination to Allah and descent from Adam. All men are equal in terms of basic human dignity and basic obligations and responsibilities, without any discrimination on the basis of race, colour, language, belief, sex, religion, political affiliation, social status or other considerations. The true religion is the guarantee for enhancing such dignity along the path to human integrity.

(b) All human beings are Allah's subjects, and the most loved by Him are those who are most beneficial to His subjects, and no one has superiority over another except on the basis of piety and good deeds.

\section{ARTICLE 2:}

(a) Life is a God-given gift and the right to life is guaranteed to every human being. It is the duty of individuals, societies and states to safeguard this right against any violation, and it is prohibited to take away life except for a shari'ah prescribed reason.

(b) It is forbidden to resort to any means which could result in the genocidal annihilation of mankind.

(c) The preservation of human life throughout the term of time willed by Allah is a duty prescribed by Shari'ah.

(d) Safety from bodily harm is a guaranteed right. It is the duty of the state to safeguard it, and it is prohibited to breach it without a Shari'ah-prescribed reason.

\section{ARTICLE 3:}

(a) In the event of the use of force and in case of armed conflict, it is not permissible to kill non-belligerents such as old men, women and children. The wounded and the sick shall have the right to medical treatment; and prisoners of war shall have the right to be fed, sheltered and clothed. It is prohibited to mutilate or dismember dead bodies. It is required to exchange prisoners of war and to arrange visits or reunions of families separated by circumstances of war.

(b) It is prohibited to cut down trees, to destroy crops or livestock, to destroy the enemy's civilian buildings and installations by shelling, blasting or any other means.

\section{ARTICLE 4:}

Every human being is entitled to human sanctity and the protection of one's good name and honour during one's life and after one's death. The state and the society shall protect one's body and burial place from desecration. 


\section{ARTICLE 5:}

(a) The family is the foundation of society, and marriage is the basis of making a family. Men and women have the right to marriage, and no restrictions stemming from race, colour or nationality shall prevent them from exercising this right.

(b) The society and the State shall remove all obstacles to marriage and facilitate it, and shall protect the family and safeguard its welfare.

\section{ARTICLE 6:}

(a) Woman is equal to man in human dignity, and has her own rights to enjoy as well as duties to perform, and has her own civil entity and financial independence, and the right to retain her name and lineage.

(b) The husband is responsible for the maintenance and welfare of the family.

\section{ARTICLE 7:}

(a) As of the moment of birth, every child has rights due from the parents, the society and the state to be accorded proper nursing, education and material, hygienic and moral care. Both the fetus and the mother must be safeguarded and accorded special care.

(b) Parents and those in such like capacity have the right to choose the type of education they desire for their children, provided they take into consideration the interest and future of the children in accordance with ethical values and the principles of the Shari'ah.

(c) Both parents are entitled to certain rights from their children, and relatives are entitled to rights from their kin, in accordance with the tenets of the shari'ah.

\section{ARTCLE 8:}

Every human being has the right to enjoy a legitimate eligibility with all its prerogatives and obligations in case such eligibility is lost or impaired, the person shall have the right to be represented by his/her guardian.

\section{ARTICLE 9:}

(a) The seeking of knowledge is an obligation and provision of education is the duty of the society and the State. The State shall ensure the availability of ways and means to acquire education and shall guarantee its diversity in the interest of the society so as to enable man to be acquainted with the religion of Islam and uncover the secrets of the Universe for the benefit of mankind.

(b) Every human being has a right to receive both religious and worldly education from the various institutions of teaching, education and guidance, including the family, the school, the university, the media, etc., and in such an integrated and balanced manner that would develop human personality, strengthen man's faith in Allah and promote man's respect to and defence of both rights and obligations. 


\section{ARTICLE 10:}

Islam is the religion of true unspoiled nature. It is prohibited to exercise any form of pressure on man or to exploit his poverty or ignorance in order to force him to change his religion to another religion or to atheism.

\section{ARTICLE 11:}

(a) Human beings are born free, and no one has the right to enslave, humiliate, oppress or exploit them, and there can be no subjugation but to Allah the Almighty.

(b) Colonialism of all types being one of the most evil forms of enslavement is totally prohibited. Peoples suffering from colonialism have the full right to freedom and selfdetermination. It is the duty of all States peoples to support the struggle of colonized peoples for the liquidation of all forms of and occupation, and all States and peoples have the right to preserve their independent identity and econtrol over their wealth and natural resources.

\section{ARTICLE 12:}

Every man shall have the right, within the framework of the Shari'ah, to free movement and to select his place of residence whether within or outside his country and if persecuted, is entitled to seek asylum in another country. The country of refuge shall be obliged to provide protection to the asylum-seeker until his safety has been attained, unless asylum is motivated by committing an act regarded by the Shari'ah as a crime.

\section{ARTICLE 13:}

Work is a right guaranteed by the State and the Society for each person with capability to work. Everyone shall be free to choose the work that suits him best and which serves his interests as well as those of the society. The employee shall have the right to enjoy safety and security as well as all other social guarantees. He may not be assigned work beyond his capacity nor shall he be subjected to compulsion or exploited or harmed in any way. He shall be entitled - without any discrimination between males and females - to fair wages for his work without delay, as well as to the holidays allowances and promotions which he deserves. On his part, he shall be required to be dedicated and meticulous in his work. Should workers and employers disagree on any matter, the State shall intervene to settle the dispute and have the grievances redressed, the rights confirmed and justice enforced without bias.

\section{ARTICLE 14:}

Everyone shall have the right to earn a legitimate living without monopolization, deceit or causing harm to oneself or to others. Usury (riba) is explicitly prohibited. 


\section{ARTICLE 15:}

(a) Everyone shall have the right to own property acquired in a legitimate way, and shall be entitled to the rights of ownership without prejudice to oneself, others or the society in general. Expropriation is not permissible except for requirements of public interest and upon payment of prompt and fair compensation.

(b) Confiscation and seizure of property is prohibited except for a necessity dictated by law.

\section{ARTICLE 16:}

Everyone shall have the right to enjoy the fruits of his scientific, literary, artistic or technical labour of which he is the author; and he shall have the right to the protection of his moral and material interests stemming therefrom, provided it is not contrary to the principles of the Shari'ah.

\section{ARTICLE 17:}

(a) Everyone shall have the right to live in a clean environment, away from vice and moral corruption, that would favour a healthy ethical development of his person and it is incumbent upon the State and society in general to afford that right.

(b) Everyone shall have the right to medical and social care, and to all public amenities provided by society and the State within the limits of their available resources.

(c) The States shall ensure the right of the individual to a decent living that may enable him to meet his requirements and those of his dependents, including food, clothing, housing, education, medical care and all other basic needs.

\section{ARTICLE 18:}

(a) Everyone shall have the right to live in security for himself, his religion, his dependents, his honour and his property.

(b) Everyone shall have the right to privacy in the conduct of his private affairs, in his home, among his family, with regard to his property and his relationships. It is not permitted to spy on him, to place him under surveillance or to besmirch his good name. The State shall protect him from arbitrary interference.

(c) A private residence is inviolable in all cases. It will not be entered without permission from its inhabitants or in any unlawful manner, nor shall it be demolished or confiscated and its dwellers evicted.

\section{ARTICLE 19:}


(a) All individuals are equal before the law, without distinction between the ruler and the ruled.

(b) The right to resort to justice is guaranteed to everyone.

(c) Liability is in essence personal.

(d) There shall be no crime or punishment except as provided for in the Shari'ah.

(e) A defendant is innocent until his guilt is proven in a fast trial in which he shall be given all the guarantees of defence.

\section{ARTICLE 20:}

It is not permitted without legitimate reason to arrest an individual, or restrict his freedom, to exile or to punish him. It is not permitted to subject him to physical or psychological torture or to any form of maltreatment, cruelty or indignity. Nor is it permitted to subject an individual to medical or scientific experiments without hisconsent or at the risk of his health or of his life. Nor is it permitted to promulgate emergency laws that would provide executive authority for such actions.

\section{ARTICLE 21:}

Taking hostages under any form or for any purpose is expressly forbidden.

\section{ARTICLE 22:}

(a) Everyone shall have the right to express his opinion freely in such manner as would not be contrary to the principles of the Shari'ah.

1.. Everyone shall have the right to advocate what is right, and propagate what is good, and warn against what is wrong and evil according to the norms of Islamic Shari'ah.

(c) Information is a vital necessity to society. It may not be exploited or misused in such a way as may violate sanctities and the dignity of Prophets, undermine moral and ethical Values or disintegrate, corrupt or harm society or weaken its faith.

(d) It is not permitted to excite nationalistic or doctrinal hatred or to do anything that may be an incitement to any form or racial discrimination.

\section{ARTICLE 23:}

(a) Authority is a trust; and abuse or malicious exploitation thereof is explicitly prohibited, in order to guarantee fundamental human rights.

(b) Everyone shall have the right to participate, directly or indirectly in the administration of his country's public affairs. He shall also have the right to assume public office in accordance with the provisions of Shari'ah. 
ARTICLE 24:

All the rights and freedoms stipulated in this Declaration are subject to the Islamic Shari'ah.

ARTICLE 25:

The Islamic Shari'ah is the only source of reference for the explanation or clarification of any of the articles of this Declaration.

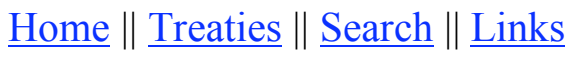




\section{Arab Charter on Huma Rights, adopted by the League of Arab States, reprinted in 18 Hum. Rts. L.J. 151 (1997).}

\section{Council of the League of Arab States, Cairo \\ Arab Charter on Human Rights}

adopted on 15 September 1994 (not yet ratified as of 30 June 1997), full text (1), translated from Arabic (2)

" The Governments of the member States of the League of Arab States (3)

\section{Preamble}

Given the Arab nation's belief in human dignity since God honoured it by making the Arab World the cradle of religions and the birthplace of civilizations which confirmed its right to a life of dignity based on freedom, justice and peace,

Pursuant to the eternal principles of brotherhood and equality among all human beings which were firmly established by the Islamic Shari'a and the other divinely-revealed religions,

Being proud of the humanitarian values and principles which it firmly established in the course of its long history and which played a major role in disseminating centres of learning between the East and the West, thereby making it an international focal point for seekers of knowledge, culture and wisdom,

Conscious of the fact that the entire Arab World has always worked together to preserve its faith, believing in its unity, struggling to protect its freedom, defending the right of nations to self-determination and to safeguard their resources, believing in the rule of law and that every individual's enjoyment of freedom, justice and equality of opportunity is the yardstick by which the merits of any society are gauged,

Rejecting racism and zionism, which constitute a violation of human rights and pose a threat to world peace,

Acknowledging the close interrelationship between human rights and world peace, Reaffirming the principles of the Charter of the United Nations and the Universal Declaration of Human Rights, as well as the provisions of the United Nations International Covenants on Civil and Political Rights and Economic, Social and Cultural Rights and the Cairo Declaration on Human Rights in Islam (4)

In confirmation of all the above, have agreed as follows : 


\section{Article 1}

(a) All peoples have the right of self-determination and control over their natural wealth and resources and, accordingly, have the right to freely determine the form of their political structure and to freely pursue their economic, social and cultural development.

(b) Racism, zionism, occupation and foreign domination pose a challenge to human dignity and constitute a fundamental obstacle to the realization of the basic rights of peoples. There is a need to condemn and endeavour to eliminate all such practices.

\section{Part II}

\section{Article 2}

Each State Party to the present Charter undertakes to ensure to all individuals within its territory and subject to its Jurisdiction the right to enjoy all the rights and freedoms recognized herein, without any distinction on grounds of race, colour, sex, language, religion, political opinion, national or social origin, property, birth or other status and without any discrimination between men and women.

\section{Article 3}

(a) No restriction upon or derogation from any of the fundamental human rights recognized or existing in any State Party to the present Charter in virtue of law, conventions or custom shall be admitted on the pretext that the present Charter does not recognize such rights or that it recognizes them to a lesser extent.

(b) No State Party to the present Charter shall derogate from the fundamental freedoms recognized herein and which are enjoyed by the nationals of another State that shows less respect for those freedoms.

\section{Article 4}

(a) No restrictions shall be placed on the rights and freedoms recognized in the present Charter except where such is provided by law and deemed necessary to protect the national security and economy, public order, health or morals or the rights and freedoms of others.

(b) In time of public emergency which threatens the life of the nation, the States Parties may take measures derogating from their obligations under the present Charter to the extent strictly required by the exigencies of the situation.

(c) Such measures or derogations shall under no circumstances affect or apply to the rights and special guarantees concerning the prohibition of torture and degrading treatment, return to one's country, political asylum, trial, the inadmissibility of retrial for the same act, and the legal status of crime and punishment. 
Every individual has the right to life, liberty and security of person. These rights shall be protected by law.

\section{Article 6}

There shall be no crime or punishment except as provided by law and there shall be no punishment in respect of an act preceding the promulgation of that provision. The accused shall benefit from subsequent legislation if it is in his favour.

\section{Article 7}

The accused shall be presumed innocent until proved guilty at a lawful trial in which he has enjoyed the guarantees necessary for his defence.

\section{Article 8}

Everyone has the right to liberty and security of person and no one shall be arrested, held in custody or detained without a legal warrant and without being brought promptly before a judge.

\section{Article 9}

All persons are equal before the law and everyone within the territory of the State has a guaranteed right to legal remedy.

\section{Article 10}

The death penalty may be imposed only for the most serious crimes and anyone sentenced to death shall have the right to seek pardon or commutation of the sentence.

\section{Article 11}

The death penalty shall under no circumstances be imposed for a political offence.

\section{Article 12}

The death penalty shall not be inflicted on a person under 18 years of age, on a pregnant woman prior to her delivery or on a nursing mother within two years from the date on which she gave birth.

\section{Article 13}

(a) The States parties shall protect every person in their territory from being subjected to physical or mental torture or cruel, inhuman or degrading treatment. They shall take effective measures to prevent such acts and shall regard the practice thereof, or participation therein, as a punishable offence.

(b) No medical or scientific experimentation shall be carried out on any person without his free consent. 
No one shall be imprisoned on the ground of his proven inability to meet a debt or fulfil any civil obligation.

Article 15

Persons sentenced to a penalty of deprivation of liberty shall be treated with humanity.

Article 16

No one shall be tried twice for the same offence.

Anyone against whom such proceedings are brought shall have the right to challenge their legality and to demand his release.

Anyone who is the victim of unlawful arrest or detention shall be entitled to compensation.

Article 17

Privacy shall be inviolable and any infringement thereof shall constitute an offence. This privacy includes private family affairs, the inviolability of the home and the confidentiality of correspondence and other private means of communication.

Article 18

Everyone shall have the inherent right to recognition as a person before the law.

Article 19

The people are the source of authority and every citizen of full legal age shall have the right of political participation, which he shall exercise in accordance with the law.

Article 20

Every individual residing within the territory of a State shall have the right to liberty of movement and freedom to choose his place of residence in any part of the said territory, within the limits of the law.

Article 21

No citizen shall be arbitrarily or unlawfully prevented from leaving any Arab country, including his own, nor prohibited from residing, or compelled to reside, in any part of his country.

Article 22

No citizen shall be expelled from his country or prevented from returning thereto. 
Every citizen shall have the right to seek political asylum in other countries in order to escape persecution. This right shall not be enjoyed by persons facing prosecution for an offence under the ordinary law. Political refugees shall not be extraditable.

\section{Article 24}

No citizen shall be arbitrarily deprived of his original nationality, nor shall his right to acquire another nationality be denied without a legally valid reason.

\section{Article 25}

Every citizen has a guaranteed right to own private property. No citizen shall under any circumstances be divested of all or any part of his property in an arbitrary or unlawful manner.

\section{Article 26}

Everyone has a guaranteed right to freedom of belief, thought and opinion.

\section{Article 27}

Adherents of every religion have the right to practise their religious observances and to manifest their views through expression. practice or teaching, without prejudice to the rights of others. No restrictions shall be imposed on the exercise of freedom of belief, thought and opinion except as provided by law.

\section{Article 28}

All citizens have the right to freedom of peaceful assembly and association. No restrictions shall be placed on the exercise of this right unless so required by the exigencies of national security, public safety or the need to protect the rights and freedoms of others.

\section{Article 29}

The State guarantees the right to form trade unions and the right to strike within the limits laid down by law.

\section{Article 30}

The State guarantees every citizen's right to work in order to secure for himself a standard of living that meets the basic requirements of life. The State also guarantees every citizen's right to comprehensive social security.

\section{Article 31}

Free choice of work is guaranteed and forced labour is prohibited. Compelling a person to perform work under the terms of a court judgement shall not be deemed to constitute forced labour. 
The State shall ensure that its citizens enjoy equality of opportunity in regard to work, as well as a fair wage and equal remuneration for work of equal value.

Article 33

Every citizen shall have the right of access to public office in his country.

\section{Article 34}

The eradication of illiteracy is a binding obligation and every citizen has a right to education. Primary education, at the very least, shall be compulsory and free and both secondary and university education shall be made easily accessible to all.

Article 35

Citizens have a right to live in an intellectual and cultural environment in which Arab nationalism is a source of pride, in which human rights are sanctified and in which racial, religious and other forms of discrimination are rejected and international cooperation and the cause of world peace are supported.

\section{Article 36}

Everyone has the right to participate in cultural life, as well as the right to enjoy literary and artistic works and to be given opportunities to develop his artistic, intellectual and creative talents.

\section{Article 37}

Minorities shall not be deprived of their right to enjoy their culture or to follow the teachings of their religions.

\section{Article 38}

(a) The family is the basic unit of society, whose protection it shall enjoy.

(b) The State undertakes to provide outstanding care and special protection for the family, mothers, children and the aged.

\section{Article 39}

Young persons have the right to be afforded the most ample opportunities for physical and mental development.

\section{Part III}




\section{Article 40}

(a) The States members of the League's Council which are parties to the Charter shall elect a Committee of Experts on Human Rights by secret ballot.

(b) The Committee shall consist of seven members nominated by the member States Parties to the Charter. The initial elections to the Committee shall be held six months after the Charter's entry into force. The Committee shall not include more than one person from the same State.

(c) The Secretary-General shall request the member States to submit their candidates two months before the scheduled date of the elections.

(d) The candidates, who must be highly experienced and competent in the Committee's field of work, shall serve in their personal capacity with full impartiality and integrity.

(e) The Committee's members shall be elected for a three-year term which, in the case of three of them, shall be renewable for one further term, their names being selected by lot. The principle of rotation shall be observed as far as possible.

(f) The Committee shall elect its chairman and shall draw up its rules of procedure specifying its method of operation.

(g) Meetings of the Committee shall be convened by the Secretary-General at the Headquarters of the League's Secretariat. With the Secretary-General's approval, the

Committee may also meet in another Arab country if the exigencies of its work so require.

\section{Article 41}

1. The States Parties shall submit reports to the Committee of Experts on Human Rights in the following manner :

(a) An initial report one year after the date of the Charter's entry into force.

(b) Periodic reports every three years.

(c) Reports containing the replies of States to the Committee's questions.

2. The Committee shall consider the reports submitted by the member States Parties to the Charter in accordance with the provisions of paragraph 1 of this article.

3. The Committee shall submit a report, together with the views and comments of the States, to the Standing Committee on Human Rights at the Arab League.

\section{Part IV}


(a) The Secretary-General of the League of Arab States shall submit the present Charter, after its approval by the Council of the League, to the member States for signature and ratification or accession.

(b) The present Charter shall enter into effect two months after the date of deposit of the seventh instrument of ratification or accession with the Secretariat of the League of Arab States.

\section{Article 43}

Following its entry into force, the present Charter shall become binding on each State two months after the date of the deposit of Its instrument of ratification or accession with the Secretariat. The Secretary-General shall notify the member States of the deposit of each instrument of ratification or accession."

\section{Footnotes}

(1) The Charter was adopted by the Council of the League of Arab States by its resolution 5437 (102nd regular session) on 15 September 1994. The original text may be obtained from the League of Arab States, Permanent Delegation to the United Nations in Geneva, 9 rue du Valais, CH-1202 Geneva.

(2) Translation by the United Nations, obtained from the Centre for Human Rights in Geneva. A French translation made by Mohammed Amin AI-Midani has been published in RUDH, Vol. 7 (1995), p. 212 ff.

(3) The 22 member States of the League of Arab States are : Jordan. United Arab Emirates, Bahrain, Tunisia, Algeria, Djibouti. Saudi Arabia, Sudan, Syrian Arab Republic. Somalia. Iraq, Oman. Palestine, Qatar, Comoros, Kuwait, Lebanon, Libyan Arab Jamahiriya, Egypt, Morocco, Mauritania, Yemen.

(4) Adopted on 5 August 1990. 